\title{
Hasedin İnsan Hayatındaki Yıkıcı Etkileri ve Çözüm Arayışları*
}

\author{
Esra İrk \\ Arş. Gör., Bursa Uludağ Üniversitesi, İlahiyat Fakültesi, Felsefe ve Din Bilimleri Ana Bilim Dalı \\ Bursa/Türkiye \\ esrairk@uludag.edu.tr \\ http://orcid.org/0000-0002-0607-9210
}

\section{İbrahim Gürses}

Prof. Dr., Bursa Uludağ Üniversitesi, İlahiyat Fakültesi, Felsefe ve Din Bilimleri Ana Bilim Dalı Bursa/Türkiye

igurses@uludag.edu.tr

http://orcid.org/0000-0002-1424-4626

\begin{abstract}
Öz: Yoksunluk hâli sonucu ortaya çıkan haset duygusu, yoğun bir acı hissi ve hayal kırıklığı ile deneyimlenir. Genellikle kötü niyet, suçluluk, aşağılık hissi, düşmanlık, saldırganlık gibi duygularla karakterize edilen haset, negatif duygulardan kıskançlık ve başkasının zararına sevinme, pozitif duygulardan gıpta ile yakından ilişkilidir. Bireyin psikolojik iyi oluş hâline etki eden haset duygusu, bireyin iç dünyasında gerilim ve çatışmalara yol açabilmekte, diğer yandan kontrol duygusunu zayıflatıp diğerine zarar verici birtakım davranışlara neden olabilmektedir. İslam geleneğinde kötü huylar kategorisinde ele alınan haset, yapısı itibariyle en başta Allah'ın iradesine, takdirine ve taksimine itiraz mahiyeti taşıdığı için dinî ve dünyevî açıdan zararlı görülmüş ve bu duygudan sakınılması tavsiye edilmiştir. Haset duygusunu inkâr etmek yerine bu duyguyu anlamak, kabullenmek ve onunla mücadele etmeye çalışmak hasetle başa çıkmada faydalı bir yol olarak görülmüştür. Bu makalede psikolojik ve dinî bakış açısına göre haset ve hasetle ilgili bazı duygular kendilerini hasetten ayıran farklılıklar ortaya konularak incelenmiş ve hasedin nedenleri üzerinde durulmuştur. Hasedin ruh sağllğı üzerindeki etkileri ile hasetle başa çıkma yolları açıklanmıştır.
\end{abstract}

Anahtar Kelimeler: Din Psikolojisi, Haset, Kıskançlık, Başkasının Zararına Sevinme, Gıpta, Sosyal Karşılaştırma, Ruh Sağlı̆̆ı

Geliş Tarihi/Received Date: 07.04.2021

Kabul Tarihi/Accepted Date: 24.11.2021

\section{Araştırma Makalesi/Research Article}

Atıf/Citation: İrk, Esra - Gürses, İbrahim. "Hasedin İnsan Hayatındaki Yıkıcı Etkileri ve Çözüm Arayışları”. Uludağ Üniversitesi İlahiyat Fakültesi Dergisi 30/2 (Aralık 2021), 389-421.

https://doi.org/10.51447/uluifd.910994

\footnotetext{
* Bu çalışma, devam etmekte olan "Değer Yıkıcı Bir Duygu Olarak Haset Psikolojisi Üzerine Bir Araştırma” başlıklı doktora tezi (Bursa: Bursa Uludağ Üniversitesi, Sosyal Bilimler Enstitüsü) esas alınarak hazırlanmıştır.
} 


\title{
The Destructive Effects of Envy in Human Life and the Search for Solutions
}

\begin{abstract}
Envy resulting from deprivation is experienced with intense pain and disappointment. Envy is usually characterized by feelings such as ill-will, guilt, inferiority, hostility, and aggression. It is also closely associated with negative feelings of jealousy and schadenfreude as well as positive feeling of benign envy. The feeling of envy, which affects the psychological well-being of the individual, can lead to tension and conflicts in the individual's inner world, on the other hand, it can weaken the sense of self-control and cause some harmful behaviors. Envy, which is considered in the category of bad habits in the Islamic tradition, is seen as harmful in terms of religion and worldly because it is an objection to Allah's will, volition, and division, and it is recommended to avoid this feeling. Instead of denying the feeling of envy, understanding it, accepting it and trying to struggle it is seen as a useful way to deal with envy. In this article envy is evaluated considering some positive and negative feelings associated to it. We approached the topic in a psychological and religious perspective, by revealing the differences that distinguish them from envy and the causes leading to envy is emphasized. The influences of envy on mental health and the ways of coping with envy is explained.
\end{abstract}

Keywords: Psychology of Religion, Envy, Jealousy, Schadenfreude, Benign Envy, Social Comparison, Mental Health.

[You may find an extended abstract of this article after the bibliography.]

\section{Giriş}

Duygular, hayatımızın temel parçasıdır ve insana ait her bir durumda var oldukları için insan psikolojisinde hangi yaratıcı ve yıkıcı etkilere sahip olduğunu öğrenme ihtiyacı hissederiz. Öte yandan toplumsal varlıklar olarak da birlikte yaşadığımız, kendilerinin bir parçası olduğumuz insanları ve onların dürtülerini, onları o yapan duyguları anlamaya ihtiyaç duyarız. Bu da bizi ve bizim dışımızdaki insanları daha iyi anlamamıza katkıda bulunur. Bu açıdan bakıldığında, yıkıcı duygular arasında belki de ilki sayılabilecek olan ve teolojilerde yedi büyük günahtan biri olarak zikredilen hasettir. Kıskançlık, öfke, nefret, düşmanlık, narsisizm gibi duygularla irtibatlı olan bu duygu, ruhsal işleyişin bütününe sirayet eder. Hasetçi kimse tıpkı kaktüs çiçeği gibi dikenli bir durumdadır ${ }^{1}$ ve içi acı verici duygularla dopdolu olduğu için sosyal ilişkilerini de bu iç dünyanın belirlediği biçimde sürdürür.

İnsan tabiatı itibarıyla birbirine zıt yönde hareket eden çeşitli duygulara sahiptir. Günümüzde oldukça aktif bir şekilde kullanılan sosyal medya sitelerindeki çeşitli görsel ve yazılı paylaşımlar, bireyin arzularını provoke etmekte, kendisini başkalarıyla fiziksel, sosyal, ekonomik vb. açılardan karşılaştırmasına yol açmaktadır. Bu

Leyla Navaro, Haset ve Rekabet Kendi Kuyruğunu Yiyen Yılan (İstanbul: Remzi Yayınevi, 2015), 41. 
karşılaştırma bireyin hayatını sahip olmadıklarına endeksli bir şekilde devam ettirmesine ve bir takım duygusal karmaşalar yaşamasına neden olabilmektedir. İstek ve arzuların gerçekleşmemesinin yanı sıra geçmişte ve şimdi yaşanan acılar, çaresizlikler, haksızlıklar, bireyi hem hayata hem de diğerlerine karşı haset duymaya yöneltir. Böyle durumlarda kişi, kendisini incinmiş ve incitilmiş hissedebilmektedir. Yaşadıklarını zihinsel olarak hazmetmekte zorlanır.

Tüm bunlardan hareketle hasedin günlük hayatta sıkça rastlanan ve yıkıcı etkileri nedeniyle üzerinde ehemmiyetle durulması gereken bir konu olduğu açıktır. Dolayısıyla bu çalışma haset ve hasetle ilişkili bazı diğer duyguları inceleyerek hasedin bireyin ruhsal yaşantısına yansımalarını ortaya koymayı amaçlamaktadır. Bunun yanında hasedin kişiler arası ilişkilerde bozucu etkisini de göstermeyi hedeflemektedir.

\section{Haset ve Hasetle İlişkili Duygular}

\subsection{Haset}

Haset antropoloji, ekonomi, psikoloji, sosyoloji, psikanaliz, felsefe, sinirbilimi, edebiyat, tarih, örgütsel davranış ve din gibi pek çok alanda karşımıza çıkan bir duygudur. ${ }^{2}$ Çok boyutlu yönü ve diğer duygularla ilişkisel niteliği itibarıyla sınırları belirgin, net ve keskin ifadelerle tanımlanabilecek bir duygu değildir. Dolayısıyla bu müphem durum hasedin gerçek karakteriyle kavranıp algılanmasını bir ölçüde zorlaştırmaktadır.

En yalın anlamıyla haset, başkasında var olan bir şeye sahip olmaya yönelik güçlü bir arzudur. ${ }^{3}$ İngilizcede hasedin karşıllğı olarak kullanılan "envy" kelimesi "kem gözle bakmak" anlamına gelen Latince "invidere" kelimesinden türemiştir. ${ }^{4}$ Hastings Din ve Etik Ansiklopedisi'nde ${ }^{5}$ hasedi, bencil ve kötücül bir duygu olarak zikretmiştir. Kökeninde tamahkarlık ve kötü niyet bulunan bu duygu, haset eden kimsenin göz koyduğu ya da istediği şeye sahip olan kişiden hoşlanmadığ 1 ve ona zarar vermek istediği anlamını taşır. Haset duygusunda, haset edilen kişiden daha aşağıda olma bilinci ve bu bilincin altında da bir rahatsızlık hâli söz konusudur. Kişi haset duyduğu

2 Russell Belk, “Benign Envy”, AMS Review 1 (2011), 117-134.

3 Aaron Ben-Ze'ev, “Envy and Jealousy”, Canadian Journal of Philosophy 20/4 (1990), 487; Richard S. Lazarus, Emotion and adaptation (NY: Oxford University Press, 1991), 122; Richard S. Lazarus - Bernice N. Lazarus, Passion and Reason: Making Sense of Our Emotions (Oxford: Oxford University Press, 1994), 31; Kenneth T. Strongman, The Psychology of Emotion: from Everyday Life to Theory (England: John Wiley \& Sons Ltd., 2003), 140; Bénédicte Vidaillet, Workplace Envy (London: Palgrave McMillan, 2008), 18; Josh Gressel, Embracing Envy: Finding the Spiritual Treasure in Our Most Shameful Emotion (Lanham: University Press of America, 2014), 9.

4 Vidaillet, Workplace Envy, 14; P.M.S. Hacker, The Passions: A study of Human Nature (Oxford: Wiley Blackwell, 2018), 192.

5 William L. Davidson, "Envy and Emulation”, Encylopedia of Religion and Ethics, ed. James Hastings (Edinburgh: 1912), 5/322. 
şeye sahip olan kimsenin kendisinden daha avantajlı olduğunu hisseder ve ona karşı hinç duyar.

Evrensel bir duygu olan haset ${ }^{6}$ her yerde kendisini gösterebilir ve her şey haset nesnesi olabilir. ${ }^{7}$ Bu nesneler güzellik, sabır, zekâ gibi belirli bir kişisel niteliğe sahip olan bir kişi, araba gibi belirli bir mülkiyet ya da yönetici/patron gibi hasetçinin sahip olmak istediği ama sahip olamadığı belirli bir pozisyon olabilir. ${ }^{8}$ Bireyin fiziksel yaşamı için ihtiyaç duyduğu gıda veya para, psikolojik iyi olma hâli için gerekli olabilecek bir nitelik, özellik veya itibar/onay ${ }^{9}$ ya da herhangi bir kimsenin bilgeliği, saygınlığı, cesareti, tevazusu gibi karakter özellikleri de haset nesneleri arasında görülebilir. ${ }^{10}$ Bir kimse iş arkadaşının daha yüksek maaş almasına, komşusunun daha başarılı çocuklarına, meslektaşının kazandığı ödüle, kardeşinin daha büyük bir evde oturmasına, arkadaşının kendisinden daha iyi bir evliliği olmasına, kız kardeşinin çalışmak zorunda olmayıp çocuklarıly birlikte evde vakit geçirmesine ve eşinin her gün evini/ç̧ocuklarını bırakıp işe gitmesine haset edebilir. ${ }^{11}$ Benzer şekilde yüzü ciddi şekilde hasar görmüş bir kadın cildi pürüzsüz olanlara, kızları olan bir baba, oğlu olan herkese haset edebilir. ${ }^{12}$ Hatta insan haset duygusuyla en yakınlarına dahi -kardeş, aile, çocuk- düşmanca hisler besleyebilir. ${ }^{13}$

Belk'in ${ }^{14}$ ifade ettiği gibi haset ister bilinçli ister bilinçsiz olsun yoğun bir duygudur. Başkasının elindekini kaybetmesini odak noktası yapan haset eden birey başarı, mevki, zenginlik gibi yoksunluğunu duyduğu şey her ne ise bu isteklerini elde edebilmek için pozitif ve doğru eylemler yerine doğrudan diğer bireyin başarısızlığını ve düşüşünü içten bir şekilde arzu etmektedir. Bu arzusu gerçekleştiği takdirde kendisini huzursuz eden durumdan kurtulacağı yanılgısına düşer. Esasında ilk zamanlar iç dünyasında bir rahatlık hisseder. Ancak bu rahatlama duygusu geçici ve aldatıcı bir avuntudur. Çünkü bu kimsenin kendisinden daha üstün kişilerle karşılaştıkça - ki her zaman daha üstün olan vardır- biteviye haset duygusuyla karşı karşıya kalması muhtemeldir.

6 Manfred Kets de Vries, Sex Money Happiness and Death: The Quest for Authenticity (New York: Palgrave Macmillan, 2009), 148.

7 Sue Cowan-Jenssen, "Envy: Everyday and Everywhere", Psychotherapy and Politics International 9/1 (2011), 48.

8 Ben-Ze'ev, Envy and Jealousy, 491.

9 George M. Foster, "The Anatomy of Envy: A Study in Symbolic Behaviour”, Current Anthropology 13 (1972), 168.

10 Leslie H. Farber, The Ways of the Will (New York: Basic Books, 1966), 238.

11 Gressel, Embracing Envy: Finding the Spiritual Treasure in Our Most Shameful Emotion, 9-10.

12 Ben-Ze'ev, Envy and Jealousy, 492.

13 Tahir Özakkaş, Bütüncül Psikoterapi (İstanbul: Litera Yayıncılık, 2016), 445.

14 Belk, “Benign Envy”, 121. 
Haset sınırsız sayıda olası hedefleri ve dipsiz derin bir tutkuyu ifade eder. Gizemli ve anlaşılması zor bir duygudur. ${ }^{15}$ Toplumsal olarak onaylanmış bir duygu olmadığı için de genellikle maskelenir. ${ }^{16}$ Çünkü haset eden bireyler bu duygunun bir tabu olduğunu ve dinî perspektiften bakıldığında kınanmış büyük bir günah olduğunu bildikleri için ${ }^{17}$ genellikle haset duygularını itiraf etmekten utanırlar. ${ }^{18}$ Yıkıcı bir güç olarak haset duygusu üzerine inşa edilen kültürel ve dinî tabular hasedin kabulünü ya da doğrudan onun hakkında konuşmayı zorlaştırmaktadır. ${ }^{19}$ Bu yüzden bireyler onu gizlemek için ekseriyetle daha fazla motive olurlar. ${ }^{20}$ Özellikle haset düşmanca duyguları ihtiva ettiğinde daha gizli tutulur ${ }^{21}$ ve kanıtlanması her zaman mümkün değildir. ${ }^{22}$ Özetle haset olumsuz bir duygu olduğu için genellikle bastırılır, inkâr edilir, gizlenir ve yeniden tanımlanır. ${ }^{23}$

Bireyin kendisi için iyi olan her şeyi kapsayan haset belli durum, olay, olgu, zaman ve ortamla mukayyet duygusal bir tutum değildir. Sınırsız bir çeşitlilik gösterebilmektedir. Herhangi bir şeyin haset nesnesi olması olasıdır. "Neden bende yok?" sorusuna ilişkin sorgulamalar ile ötekini yargılamalar ve tasvip edilmeyen hisler hasedin özünü oluşturur. Bu aynı zamanda duygu dünyasında bir belirsizlik ve karmaşayı da beraberinde getirir.

\subsection{Kıskançlik}

Hasetle yakından ilişkili bir duygu olan kıskançlık "bize ait olan bir şeyi koruma hissi” anlamına gelmektedir. ${ }^{24}$ Ingilizcede kıskanç kelimesinin karşılığı olan jealous

15 Gressel, Embracing Envy: Finding the Tpiritual Treasure in Our Most Shameful Emotion, 10.

16 Hacker, The Passions: A Study of Human Nature, 229.

17 Vidaillet, Workplace Envy, 22.

18 Solomon Schimmel, "Envy in Jewish Thought and Literature", Envy: Theory and Research, ed. Richard H. Smith (New York: Oxford University Press, 2008), 22.

19 Leyla Navaro-Sharan L. Schwartzberg, "Conclusions and Therapeutic Implications", Envy Competition and Gender: Theory Clinical Applications and Group Work, ed. Leyla Navaro-Sharan L. Scwartzberg (New York: Routledge, 2007), 205.

20 Mark D. Alicke - Ethan Zell, "Social Comparison and Envy", Series in Affective Science Envy: Theory and Research, ed. Richard H. Smith (New York: Oxford University Press, 2008), 77.

21 Norman T. Feather-Rebecca Sherman, "Envy, Resentment, Schadenfreude, and Sympathy: Reactions to Deserved and Underserved Achievement and Subsequent Failure", Personality and Social Psychology Bulletin 28/7 (2002), 953.

22 Helmut Schoeck, Envy: A Theory of Social Behavior (New York: Harcourt Brace \& World, 1969), 112.

23 Gordon Clanton, "Jealousy and Envy”, Handbook of the Sociology of Emotions, ed. Jan. E. Stets - Jonathan. H. Turner (New York: Springer, 2006), 412.

24 Gressel, Embracing Envy: Finding the Spiritual Treasure in Our Most Shameful Emotion, 9. 
kelimesi Yunanca zelos sözcüğünden türemiştir. Zelos öykünme, rekabet, gayret anlamına gelmekte ve duygu yoğunluğuna işaret etmektedir. ${ }^{25}$ Kıskançlık, bir kişinin çok önemli ve değerli bir şeye sahip olması ve başka birinin kendisini bu şeyden mahrum bırakmasından korkmasıyla ortaya çıkmaktadır. ${ }^{26}$ Mevcut bir ilişkiyi kaybetme ihtimaline dayanır. Kıskançlık, hem bizim için önemli birinin duygusal yakınlığını kaybedebileceğimiz tehdidine hem de bu duygusal yakınlığın başka birine yönelme tehdidine karşı verilen bir tepkidir. ${ }^{27}$ Algılanan tehdit gerçek veya sanal olabilir. ${ }^{28}$ Tipik bir kıskançlık durumunda nesne bir insandır ve o kişiyle olan değerli ilişkinin kaybedilmesinden kayg duyulur. Ancak daha az tipik durumlarda bir partner ve rakip tarafından yerine getirilen rol cansız bir nesne tarafından da sağlanabilir. Örneğin, zamanının çoğunu müziğe vakfetmiş bir kadının kocasının, müziği kıskandığı söylenebilir. Müzik örneği atipiktir, çünkü gerçek bir rekabet yoktur. Müzik cansız bir nesne olduğu için kocanın kendisini mağlup ve bu rekabette daha aşağı görmesi gerekmez. Ancak kıskançlığın tipik örnekleri üçüncü bir kişinin varlı̆̆ı ile değerli bir ilişki üzerinde rekabet eden iki insanı içerir. ${ }^{29}$ Kıskançlık duygusu için gerçek ya da hayali bir rakibin varlığı gereklidir. ${ }^{30}$ Kıskançlık özel anlam yüklenen ikili ilişkilerde üçüncü bir kişinin bu ilişki sahasına girme potansiyeline yönelik ortaya çıan duygusal bir tutumdur.

Haset ve kıskançlık duyguları günlük hayatta oldukça karıştırılmakta ve eş anlamlı olarak kullanılabilmektedir. Ancak bu iki duyguyu özdeş kabul etmek yanıltıcı bir yaklaşımdır. Öte yandan bu iki duygu birbirinden bağımsız ve ayrılmış da değildir. Nitekim Smith, Kim ve Parrott ${ }^{31}$ tarafından haset ve kıskançlık duygularının hem semantik hem de ampirik açıdan incelendiği çalışmada, haset ve kıskançlık kavramlarının birbirlerinin yerine kullanıldığı görülmüştür. Bu kavramlarda görülen lengüistik belirsizlik haset kelimesinden ziyade kıskançlık kelimesinin değişken/esnek anlamından kaynaklanmaktadır. Bu belirsizliğin giderilmesi için çalışmamızda haset ve kıskançlık arasındaki temel farkları ele almayı gerekli görmekteyiz.

Haset ve kıskançlık duygularını birbirinden farklı kılan unsurlar şunlardır: (i) Bu iki duygu hem niteliksel hem de ortaya çıktıkları bağlamlar açısından birbirinden

25 Philip M. Spielman, "Envy and Jealousy an Attempt at Clarification", Psychoanalytic Quarterly 40 (1971), 63; Foster, "The Anatomy of Envy: A Study in Symbolic Behaviour", 167; Ayala Malach Pines, Aşk ve Kıskançllk, çev. Canan Yonsel (ìstanbul: Okyanus Yayınları, 2003), 16.

26 Schimmel, "Envy in Jewish Thought and Literature", 19.

27 Strongman, The Psychology of Emotion, from Everyday Life to Theory, 140.

28 Pines, Aşk ve Kıskançlı, 18.

29 Aaron Ben-Ze'ev, The Subtlety of Emotions (Cambridge, MA: MIT Press, 2001), 291.

30 Mick Power - Tim Dalgleish, Cognition and Emotion: From Order to Disorder (Hove, U.K.: Taylor Francis, 2007), 286.

31 Richard H. Smith vd., "Envy and Jealousy Semantic Problems and Experiential Distinctions", Personality and Social Psychology Bulletin 14/2 (1988), 407. 
farklıdır. Haset, gelişimsel olarak birincil bir duygudur ve kıskançlık olmaksızın ortaya çıkabilir. ${ }^{32}$ (ii) Haset bir şeyi elde etme, kıskançlık ise elde edilen şeyi kaybetmeme arzusudur. ${ }^{33}$ (iii) Haset, genellikle iki kişiliktir ve başkasının zevk aldığı bir şeyden yoksunluk hâlinde oluşur. Kıskançlık ise tipik olarak üç kişiliktir ve birini kaybetme korkusu oluştuğunda ortaya çıkar. Haset ve kıskançlık, farklı durumlardan kaynaklanır ve kendine özgü duygusal deneyimler üretir..$^{34}$ (iv) Her iki duygu da arzu nesnesine sahip olmakla ilgilidir. Ancak algılanma noktasında farklılık mevcuttur. Haset eden ötekinin sahip olduğu nesnenin mahrumiyeti nedeniyle acı çeken, hınç duyan veya kendini aşağıda hisseden biri olarak algılanabilir. Kıskanç ise sahip olduğu bir şeyi kaybetmiş bir kurban olarak algılanabilir..$^{35}$ (v) Haset toplum tarafından onaylanmaz ancak kıskançlık makul karşılanabilir. Hatta aşırı kıskançlıktan dolayı işlenen bazı suçlar hafifletici kabul edilmekte ve cezası da görece azaltılmaktadır. ${ }^{36}$ (vi) Haset etmek ekseriyetle utanç verici olarak kabul edilir. Ancak bireyin meşru olarak sahip olduğu bir şeyi korumak için kıskançlık göstermesi çok daha kabul edilebilir bir durumdur. ${ }^{37}$ (vii) Haset aşağılık duygusu, memnuniyetsizlik, isteklilik ve hasret, özeleştiri ve kendini geliștirme motivasyonu ile karakterize edilirken kıskançlık şüphecilik, reddedilme, düşmanlık, öfke, kaybetme korkusu, incitme ve diğer benzer duygularla karakterize edilir. ${ }^{38}$ (viii) Bazı durumlarda haset, negatif değerlendirmenin kişinin tüm yönlerine atfedildiği nefrete benzer. Kıskançlık ise negatif değerlendirmenin kişinin belirli bir davranışsal yönüne atfedildiği öfkeye nispeten benzer. Nefret gibi haset de genellikle özgül koşullarla sınırlı olmayan genel özelliklere yönelik olarak daha kalıcı olma eğilimindedir. Kıskançlık ise belli bir kişiye matuf geçici bir duygusal tepkiden doğar. ${ }^{39}$ (ix) Haset başkasında olup arzu oluşturan bir nesneye yönelik iken kıskançlık kendine ait olanı saklamaya çalışır. Kıskanç kimse

32 Frank John Ninivaggi, Envy Theory: Perspectives on the Psychology of Envy (Lanham, MD:Rowman \& Littlefield Publishers, 2010), 200.

33 Guy Delpierre, Kıskançlık, çev. Halis Özgü (İstanbul: Özgü Yayınevi, 1967), 26; Foster, “The Anatomy of Envy: A Study in Symbolic Behaviour", 168; Smith, vd., "Envy and Jealousy Semantic Problems and Experiential Distinctions”, 402; Ben-Ze'ev, Envy and Jealousy, 489; Ben-Ze'ev, The Subtlety of Emotions, 326; W. Gerrod Parrott, "The Emotional Experience of Envy and Jealousy”, The Psychology of Jealousy and Envy, ed. Peter Salovey (New York: Guilford Press, 1991), 23; Richard H. Smith-Sung Hee Kim, “Comprehending Envy”, Psychological Bulletin 133/1 (2007), 49; Hacker, The Passions: A Study of Human Nature, 229.

34 Smith - Kim, “Comprehending Envy”, 47.

35 Laura Quintanilla -Kristine Jensen de López, "The Niche of Envy: Conceptualization, Coping Strategies, and the Ontogenesis of Envy in Cultural Psychology", Culture \& Psychology 19/1 (2013), 78.

36 Betty Joseph, "Envy in Everyday Life", Psychoanalytic Psychotherapy 2/1 (1986), 14.

37 Schimmel, "Envy in Jewish Thought and Literature", 19.

38 Smith vd., "Envy and Jealousy Semantic Problems and Experiential Distinctions", 407.

39 Ben-Ze'ev, Envy and Jealousy, 503. 
sahip olduklarının görünmemesini ister, perdeler, saklar, kapatır. Hasetçi kimse kendisinin olmayana sahip olmak ister ve kem bakışa neden olur..$^{40}$ (x) Kıskançlik, hasetten daha fazla savunmasızlık oluşturur. Kıskançlı̆̆ın benlik saygımızda derin bir yaralanmaya neden olma olasılığı daha yüksektir. ${ }^{41}$

Haset ve kıskançlığın birbirini etkileyen ve birbirinden ayrılan yönleri olduğu kadar, süreç içinde birinin diğerine baskın geldiği ya da birinin diğerine evrildiğini söylemek mümkündür. En dar anlamda 'haset var olmayanı elde etme çabası, kıskançlık var olanı muhafaza etme çabası' ekseninde biçimlenen iki ana duygudur. Bu iki duygu farklı zaman dilimlerinde ortaya çıkmakta ve farklı duygusal durumlara yol açmaktadır. Bu duyguların kişisel ve toplumsal alanda görünürlüğü, açıklanması, yorumlanması ve algılanması çeşitlilik arz etmektedir.

\subsection{Başkasının Zararına Sevinme: Schadenfreude}

Hasetle ilişkilendirilen bir diğer duygu ise schadenfreude* kavramıla ifade edilen "başkasının talihsizliğinden zevk alma"/"başkasının zararına sevinme" duygusudur. Almanca schaden ac1, zarar; freude zevk, keyif anlamına gelmektedir. ${ }^{42}$ Pasif, dolaylı ve firsatçı bir zevk (ing. opportunistic pleasure) olarak kavramsallaştırılan başkasının zararına sevinme duygusu ${ }^{43}$ ötekinin başarısızlığına veya yenilgisine sevinmek anlamına gelir ${ }^{44}$ ve birbirinden farklı duygusal ve sosyal zeminde ortaya çıkar. ${ }^{45}$ Ben $\mathrm{Ze}^{\prime} \mathrm{ev}^{46}$ başkasının zararından duyulan sevincin herhangi bir kimse için duyulan mutluluktan daha farklı olduğunu belirtir. Başkasının zararına sevinmede duygu boyutu

40 Özgür Taburoğlu, Nazar Başkası Nasıl Görür? (Ankara: Doğu Batı Yayınları, 2017), 35.

41 Ben-Ze'ev, The Subtlety of Emotions, 290.

* Bu makalede 'schadenfreude' kavramının karşılığı olarak 'başkasının zararına sevinme’ ifadesi kullanılmiştır.

42 Joseph Shrand - Leigh Devine, Outsmarting Anger: 7 Strategies for Defusing Our Most Dangerous Emotion (San Francisco: Jossey-Bass, 2013), 70; Wilco W. Van Dijk-Jaap W. Ouwerkerk, "Introduction to Schadenfreude", Schadenfreude: Understanding Pleasure at the Misfortune of Others, ed. Wilco W. van Dijk - Jaap W. Ouwerkerk (Cambridge: Cambridge University Press, 2014), 1; Seda Erzi, Başkasının Zararına Sevinme-Schadenfreude (Ankara: Nobel Bilimsel Eserler, 2019), 1; Tiffany Watt Smith, Schadenfreude: Başkasının Talihsizliğinden Duyulan Keyif, çev. Nüvit Bingöl (İstanbul: Kolektif Kitap, 2020), 20.

43 Colin Wayne Leach vd., "Situating Schadenfreude in Social Relations", Schadenfreude: Understanding Pleasure at the Misfortune of Others, ed. Wilco W. van Dijk - Jaap W. Ouwerkerk (Cambridge: Cambridge University Press, 2014), 201.

${ }^{44}$ Joseph Epstein, Envy: The Seven Deadly Sins (New York: Oxford University Press,2003), 69-71.

45 Giselinde Kuipers, "Schadenfreude and Social Life: A Comparative Perspective on the Expression and Regulation of Mirth at the Expense of Others", Schadenfreude: Understanding Pleasure at the Misfortune of Others, ed. Wilco W. van Dijk - Jaap W. Ouwerkerk (Cambridge: Cambridge University Press, 2014), 262.

46 Aaron Ben-Ze'ev, “Pleasure at Another's Misfortune”, Iyyun The Jerusalem Philosophical Quarterly 41 (1992), 51. 
daha yoğundur ve daha spesifik koșullarla sınırlıdır. Bu duygu bireyin memnuniyeti ve diğerinin talihsizliği ile karakterize edilse de başka tipik özellikleri de vardır. Diğer kişinin talihsizliği hak ettiği düşünülür ve bu talihsizlik nispeten küçüktür. ${ }^{47}$ Leach ve arkadaşları $\mathrm{da}^{48}$ insanlara zarar veren doğal afetlerin veya ciddi başarısızlıkların çoğu insanı mağdurlara sempati duymaya yönelttiğini ifade ederler.

Geleneksel görüş başkasının zararına sevinmeyi hasetten çok daha güçlü bir biçimde kınamaktadır. Çünkü bu duygu zalimliğin, sadizmin ve nefretin bir prototipi olarak görülmektedir. ${ }^{49}$ Bu görüşe karşılık Ben Ze'ev ${ }^{50}$ başkasının zararına sevinmenin nefret, zulüm ve sadizmden farklı olduğunu düşünmektedir. Ona göre sadizm bir karakter özelliğidir, bir duygu değildir. Sadizmdeki temel bileşen, başkalarına işkence/eziyet edilmesiyle kazanılan memnuniyettir. Sadizmdeki haz öznenin kişisel dahlini içerir, nesnenin acı çekmesinden özne sorumludur. Hâlbuki başkasının zararına sevinmede durum farklıdır. Buradaki memnuniyet esas olarak öznenin geçici üstün konumundan kaynaklanmaktadır. Öznenin aktif bir katılımını gerekli kılmaz.

Psikologların bir kısmı başkasının zararına sevinmenin, haset duygusundan beslendiğine inanırken bir kısmı da hınç duygusunun başkasının zararına sevinmenin arkasındaki esas güç olduğuna inanmaktadır. ${ }^{51}$ Nitekim haset ve başkasının zararına sevinme ilişkisini inceleyen ilk ampirik araştırma ${ }^{52}$ sonucunda, haset duygusunun başkasının zararına sevinme duygusu üzerinde anlamlı bir etkiye sahip olduğu tespit edilmiştir. Katılımcıların üstün başarılı öğrencinin röportajını izlediklerinde, ortalama öğrencinin röportajını izleyenlere oranla üstün öğrencinin başına gelen talihsizliğe daha çok memnun oldukları görülmüştür. Brigham ve arkadaşlarının ${ }^{53}$ yaptığg diğer çalışma sonucunda ise katılımcıların üstün öğrencinin başına gelen talihsizliği hak edip etmediğine bakmaksızın onun zararına sevindikleri görülmüştür. Diğer

47 Ben-Ze'ev, The Subtlety of Emotions, 355-358.

48 Leach vd., "Situating Schadenfreude in Social Relations", 213.

49 Ben-Ze'ev, The Subtlety of Emotions, 377.

50 Ben-Ze'ev, "Pleasure at Another's Misfortune", 49.

51 Epstein, Envy: The Seven Deadly Sins, 73-75.

52 Richard H. Smith vd., "Envy and Schadenfreude", Personality and Social Psychology Bulletin 22/2 (1996), 162-165. Bu araştırmada katılımcılara tıp fakültesine hazırlanmakta olan bir öğrencinin videoya çekilmiş röportajı izletilmiştir. Bu öğrencinin akademik başarı ve çeşitli etkinlikler açısından ortalama veya üstün niteliklere sahip biri olarak görünmesi sağlanmıştır. (Bu videodan önce katılımcılardan haset ölçeğini doldurmaları talep edilmiştir). Gördüklerine dair duygusal tepkiler veren katılımcılara video bitiminde öğrencinin üniversite araştırma laboratuvarından amfetamin çalmaktan tutuklandığı ve dolayısıyla tıp fakültesi için planlarını geciktirmek zorunda kaldı̆̆ı konusunda bilgilendirici bir epilog sunulmuştur. Bu epilogdan sonra katılımcıların başkasının zararına sevinme ile sempati duyguları ölçülmüştür. Araştırma sonunda haset duygusunun, başkasının zararına sevinme duygusu üzerinde anlamlı bir etkiye sahip olduğu tespit edilmiştir.

53 Nancy. L Brigham, vd., "The Roles of Invidious Comparisons and Deservingness in Sympathy and Schadenfreude", Basic and Applied Social Psychology 19/3 (1997), 374-376. 
yandan çeşitli araştırma bulguları hınç $c^{54}$, hedefe yönelik olumsuz duygular ${ }^{55}$, düşük benlik saygisis ${ }^{56}$, aşağılık duygusu ${ }^{57}$, hak etme durumu ${ }^{58}$ ile başkasının zararına sevinme duygusu arasında da anlamlı bir ilişki bulunduğunu ortaya koymaktadır. $\mathrm{Bu}$ bağlamda başkasının zararına sevinme duygusunu doğrudan kişilik bozukluğu olarak değerlendirmek yahut hasedin her zaman zorunlu olarak başkasının zararına sevinmeye yol açacağını düşünmek yanıltıcı ve yanlış bir çıkarsama olacaktır. Bireyin geçmiş yaşantıları, içsel deneyimleri, duygu durumları gibi değişkenler başkasının zararına sevinme duygusunda belirleyici olabilmektedir. Başkasının zararına sevinme bireyin mağlubiyeti ve yoksunluğu neticesinde içten gelen bir hisle derinden bağlantılıdır. Tatminsizlik, bireyi içten içe kemiren yetersizlik ve başaramamışlık duygusu bu şekilde kısmen teskin edilmektedir. Bu duygu bireye nisbî, göreceli ve sathî bir kazanım sağlamaktadır. Birey mağlup olduğu yenilgiler sonrası ötekinin talihsizliği karşısında kazanmışlı duygusu hisseder. Bu, bir bakıma kısmî bir zaferin sembolüdür. Haset edilenin başına gelen herhangi bir talihsizlik ya da zarar, birey için beklenmedik, hoş bir sürpriz gibidir. Çünkü bu fiil kendi eylemi değildir hem de haset edilen kişi hak ettiği şeyi nihayetinde bulmuştur. Ancak bireyin yaşadığ 1 bu tatmin duygusu her ne kadar kendisine görece bir rahatlık ve haz verse de bilinçaltında bireyin bu duyguyu hissetmesine neden olan etkenler örtük bir şekilde varlığını sürdürmektedir.

\section{Haset ve Gipta}

Haset duygusu semantik açıdan olumsuz bir durumu ifade etmekle birlikte alan yazınında haset iki boyutlu ele alınmıştır. Bu boyutlardan biri hasedin kötücül yönüne (ing. malicious envy) işaret ederken, diğeri gıpta (ing. benign envy) olarak adlandırılan hasedin iyicil yönüne işaret etmektedir. ${ }^{59} \mathrm{Bu}$ olumlu yön içinde düşmanlık

54 Feather -Sherman, "Envy, Resentment, Schadenfreude, and Sympathy: Reactions to Deserved and Underserved Achievement and Subsequent Failure", 960.

55 Shlomo Hareli-Bernard Weiner, "Dislike and Envy as Antecedents of Pleasure at Another's Misfortune", Motivation and Emotion 26/4 (2002), 272.

56 Wilco W. Van Dijk vd, "Self-esteem, Self-affirmation, and Schadenfreude", Emotion 11/6 (2011), 1447; Seda Erzi, "Yardım Davranışlarının Schadenfreude, Benlik Saygısı ve Benlik Tehdit Algısı Bakımından İncelenmesi”, Kastamonu Eğitim Dergisi 27/3 (2019), 1018.

57 Colin Wayne Leach-Russell Spears, "A Vengefulness of the İmpotent: The Pain of in-group Inferiority and Schadenfreude toward Successful out-groups", Journal of Personality and Social Psychology 95/6 (2008), 1387.

58 Norman T. Feather-Katherine Nairn, "Resentment, Envy, Schadenfreude, and Sympathy: Effects of Own and Other's Deserved or Undeserved Status", Australian Journal of Psychology 57/2 (2005), 94.

59 John Rawls, A theory of Justice (Cambridge, MA: Harvard University Press, 1971), 467; Richard H. Smith, "Envy and the Sense of Injustice", The Psychology of Jealousy and Envy, ed. Peter Salovey (Guilford Press, 1991), 93-96; Niels Van de Ven, vd., "Leveling up and down: The Experiences of Benign and Malicious Envy", Emotion 9/3 (2009), 423; Jan Crusius - Jens Lange, "What Catches the Envious Eye? Attentional Biases within Malicious and Benign Envy”, Journal of Experimental Social Psychology 55 (2014), 9; Jens 
barındırmayan, hayranlığa benzeyen bir duygudur. ${ }^{60}$ Gıptadaki düşmanca duyguların yokluğu, bu duyguyu hem hissedilen deneyim hem de sonuçları açısından temelde hasetten farklı k1lmaktadır. ${ }^{61}$ Gıpta, hasetten farklı olarak kendini geliștirme konusunda kararlllık ve hayranlık duygusu ile deneyimlenir. ${ }^{62}$ Bireylerin kendilerini geliştirmelerini sağlayan itici bir güçtür. Gipta bireylere daha iyi bir konuma gelmek için çaba harcama yönünde bir motivasyon sağlarken, haset diğerini aşağıya çekme yönünde bir motivasyon sağlamaktadır. ${ }^{63}$ Nitekim Van de Ven, Zeelenberg ve Pieters'in ${ }^{64}$ gerçekleştirdiği bir çalışmada gıptanın kişinin kendisini geliştirmesi için motive edici bir değer olarak ortaya çıktığı görülmüsstür. Buna göre yukarı doğru karşılaştırmayı takiben kendisine oranla daha iyi performans sergileyen kişilere karşı gıpta hisseden öğrencilerin, gelecek sömestre döneminde çalışmalarına çok daha fazla zaman ayırmayı planladıkları tespit edilmiştir.

Hem haset hem de gıpta sosyal karşılaştırma ile ortaya çıkmaktadır. Birey kendisi için önemli olan bir konuda kendisinden daha üstün olan birinin varlığının farkına vardığında haset duygusu deneyimlenir. Bu karşılaştırma neticesinde birey kendisinde gördüğü eksikliklerin nedeni olarak haset ettiği kişiyi hedef alırsa, hasedin kötücül tabiatındaki düşmanlık ve nefret ortaya çıkar. Ancak, tersi bir şekilde, birey haset edilen kişiyi hedef almadan, kendisine ve kendi eksikliklerine odaklanırsa gıpta duygusu belirgin olur. ${ }^{65}$

Kontrol algısının düşük/yüksek olması ve haset edilen kimsenin üstünlüğünün hak edilmiş olması/olmaması, haset ya da gıpta duygusunun ortaya çıkmasında belirleyici olmaktadır. ${ }^{66}$ Sosyal karşılaştırma durumunda kontrol algısı yüksek (kendilerini arzu edilen nesneye ulaşabilecek durumda gören) bireylerin kendi kişisel gelişimlerine yönelme olasılığı daha yüksek iken, kontrol algısı düşük bireylerde ise hasedin, düşmanlık veya depresyona yol açma olasılığı daha yüksektir. ${ }^{67}$ Nitekim Testa

Lange - Jan Crusius, “Dispositional Envy Revisited: Unraveling the Motivational Dynamics of Benign and Malicious Envy", Personality and Social Psychology Bulletin 41/2 (2015), 292.

60 Smith, "Envy and the Sense of Injustice", 93-96; Smith-Kim, "Comprehending Envy", 47; Caitlin A. J. Powell, vd., "Schadenfreude Caused by an Envied Person's Pain", Series in Affective Science Envy: Theory and Research, ed. Richard H. Smith (New York: Oxford University Press, 2008), 161.

61 Smith - Kim,“Comprehending Envy”, 47.

62 Parrott, "The Emotional Experience of Envy and Jealousy", 10.

63 Van de Ven, "Leveling up and down: The Experiences of Benign and Malicious Envy", 421.

64 Niels Van de Ven, vd., "Why Envy Outperforms Admiration”, Personality and Social Psychology Bulletin 37/6 (2011b), 786.

65 Parrott, "The Emotional Experience of Envy and Jealousy", 12.

${ }^{66}$ Jan Crusius vd., "Envy: An Adversarial Review and Comparison of Two Competing Views”, Emotion Review (2019), 12.

67 Nicole E. Henniger - Christine R. Harris, “Can Negative Social Emotions Have Positive Consequences?: An Examination of Embarrassment, Shame, Guilt, Jealousy, and Envy", The Positive Side of Negative Emotions, ed. W. Gerrod Parrott (New York: The Guilford Press, 2014), 91. 
ve Major ${ }^{68}$ tarafından gerçekleştirilen araştırma sonucunda, kontrol algısı düşük olan katılımcılar arasında gerçekleşen yukarı doğru karşılaştırmalarda hasedin, artan depresyon ve düşmanlığa yol açtığı tespit edilmiştir.

Hasedin tahrip edici, bozucu, köreltici doğası ile ilgili tüm olumsuz vurgu ve nitelemelere rağmen, haset giptaya evrilerek bireyin kendini geliştirmesine ve tamamlamasına da izin verebilir. Bireyin çok yönlü sorgulamalar yapmasını sağlayarak, yenilenmeci bir refleksi beraberinde getirebilir. Bu minvalde haset hem ilerletici hem de engelleyici özü bünyesinde taşır. Hasedin bu iki tür seyrine etki eden değişkenlerden biri de oto-kontrol duygusudur. Durumunu değiştirebilme potansiyelini kendinde gören bireyler gıpta duygusunu daha çok deneyimlemektedir. Bu da onların bilişsel ve motivasyonel kaynaklarını kullanma ihtimallerini yükseltmektedir. Ancak öz-kontrol ve öz-denetim mekanizmaları zayıf olan bireyler hasedi deneyimlemekte ve ötekine yönelik yetersiz bir duygu kontrolü sergilemektedir.

\section{1. İslam Düşüncesinde Haset ve Gipta}

İslam alimleri hasedi, Allah'ın başkasına vermiş olduğu makam-mevki, zenginlik, yetenek, güzellik ve iyiliklere göz dikme ve yok olmasını isteme olarak tanımlamışlardır. ${ }^{69}$ İsfahânî ${ }^{70}$ haset duygusunun sadece temenni ile kalmayıp bireyin elinden gitmesi için çaba göstermeyle birleşebileceğini de ifade eder. Öyle anlaşllyyor ki İslam alimleri hasedin 'göz dikme', 'hoşlanmama', 'çekememe', 'zevalini isteme' gibi olumsuz duyguları ihtiva ettiği konusunda ittifak hâlindedirler.

Kur'ân'da haset kavramı ile ilgili ayetler* incelendiğinde hasedin iyiliği bozan, kötülüğü yapılandıran, iyi olanın dışında her bir şeye bireyi yönelten ve şerrinden

68 Maria Testa-Brenda Major, "The Impact of Social Comparison After Failure: The Moderating Effects of Perceived Control", Basic and Applied Social Psychology 11 (1990), 213.

${ }^{69}$ Muhammed Abduh - Muhammed Reşîd Rızâ, Menâr Tefsiri: Tefsiru'l-Kur'an-i'l-Hakîm, çev. Mehmet Erdoğan vd. (İstanbul: Ekin Yayınları, 2011), 14/492; Elmalılı Muhammed Hamdi Yazır, Hak Dini Kur'ân Dili, sad. İsmail Karaçam vd. (İstanbul: Zehraveyn Yayınları, 1992), 10/171; İbn Kayyım el-Cevziyye, İbn Kayyim Tefsiri: Bedâi'u't-tefsîr, der. Yüsrî es-Seyyid Muhammed, çev. Mehmet Ali Kara vd. (İstanbul: Polen Yayınları, 2011), 4/661; Ebu'l-Leys Nasr b. Muhammed b. Ahmed b. İbrâhim es-Semerkandî, Tefsîru'l-Kur'an, çev. Mehmet Karadeniz (İstanbul: Özgü Yayınları, 1993), 6/494.

70 Ebu'l-Kāsım er-Râgıb el-İsfahânî, Müfredât: Kur'ân Kavramları Sözlüğü, çev. Abdulbaki Güneş - Mehmet Yolcu (ìstanbul: Çıra Yayınları, 2012), 282; a. mlf., ez-Zerîa ilâ makāmi'l-şerî́a: Erdemli Yol, çev. Muharrem Tan (İstanbul: İz Yayıncıllk, 2019), 261.

* Allah'ın meleklerden Hz. Âdem'e secde etmesini emretmesiyle ortaya çıkan haset ve kibir aynı zamanda Allah'a isyanın ilk nedenidir. Bu olay Kur'ân'da şöyle anlatılmaktadır: "Hani, Rabbin meleklere, 'Ben yeryüzünde bir halife yaratacağım' demişti. Onlar, 'Orada bozgunculuk yapacak, kan dökecek birini mi yaratacaksın? Oysa biz sana hamd ederek daima seni teşbih ve takdis ediyoruz'. demişlerdi. Allah da 'Ben sizin bilmediğinizi bilirim' demişti... Hani meleklere, 'Âdem için saygı ile eğilin' demiştik de i̇blis hariç bütün melekler saygı ile eğilmişler; İblis (bundan) kaçınmış, büyüklük taslamış ve kafirlerden olmuştu." (el-Bakara 2/30-34). Şeytan kendi varlığının ateşten, Hz. Âdem'in balçıktan yaratılmasını kendi adına bir üstünlük olarak 
Allah'a sığınılması gereken yok edici bir duygu olduğu hemen fark edilir. Neden olduğu yıkıcı durumlar çeşitli kıssalarla da açıklanmıştır. Buradan hareketle hasedin en tipik biçimde, büyüklenme, hırs, zulüm, kıskançlık, hınç, düşmanlık gibi diğer duygularla birlikte hareket ettiğini rahatlıkla söyleyebiliriz.

Bu yüzden Kur'ân-1 Kerîm'de hasetçinin şerrinden kaçınılması, Allah'a sığınılması gerektiği açıkça ifade edilmektedir. Bu durum Felak Sûresi'nin* son ayetinde

görüp secde etmemekte diretmiş, kendisinden daha aşağı bir varlığa Allah tarafından bu kadar çok iltifat edilmesine haset etmiş, nankörlerden olmuştur. Yeryüzünde işlenen ilk cinayet ve ilk kardeş katlinin haset nedeniyle meydana gelmesi hasedin acımasız ve vahşî doğasını göstermesi açısından oldukça kayda değer bir hadisedir. Hz. Âdem'in oğlu Kâbil, kardeşi Hâbil'i öldürmüş ve haset nedeniyle işlenen ilk cinayetin müsebbibi olarak zikredilmiştir. Bu olay Kur'ân-1 Kerîm'de şöyle anlatılmaktadır: “(Ey Muhammed!) Onlara, Âdem'in iki oğlunun haberini gerçek olarak oku: Hani ikisi de birer kurban sunmuşlardı da birinden kabul edilmiş, ötekinden kabul edilmemişti. Kurbanı kabul edilmeyen, 'Andolsun seni mutlaka öldüreceğim.' demişti. Öteki, 'Allah, ancak kendisine karşı gelmekten sakınanlardan kabul eder' demişti.... Derken nefsi onu kardeşini öldürmeye itti de (nefsine uyarak) onu öldürdü ve böylece ziyan edenlerden oldu." (el-Mâide 5/27-31). Kâbil, hasedin tetiklediği öfke, hırs, hiddet ve intikam duygusuyla telafisi mümkün olmayan bir fiil gerçekleştirmiştir. Elmalılı bu fiilin zarar verme arzusundan ve hasetten dolayı işlendiğine işaret eder. Elmalılı Muhammed Hamdi Yazır, Hak Dini Kur'ân Dili, 3/226. Benzer şekilde Hz. Yâkūb'un oğullarının Hz. Yusuf'u kıskanmalarından ve ona haset etmelerinden dolayı gerçekleştirdikleri kötü fiili Kur'ân-1 Kerîm bize haber vermektedir: "Kardeşleri dediler ki: "Biz güçlü bir topluluk olduğumuz hâlde, Yusuf ve kardeşi (Bünyamin) babamıza bizden daha sevgilidir. Doğrusu babamız apaçık bir yanılgı içindedir. Yusufu öldürün veya onu bir yere atın ki babanız sadece size yönelsin. Ondan sonra (tevbe edip) salih kimseler olursunuz. Onlardan bir sözcü, 'Yusufu öldürmeyin, onu bir kuyunun dibine bırakın ki geçen kervanlardan biri onu bulup alsin. Eğer yapacaksanız böyle yapin' dedi." (Yûsuf 12/8-10). Yusuf un kardeşleri sırf hasetlerinden dolayı Yusuf (a.s)'ı yok etmeye, onu babasından ayırmaya, köle hâline getirmeye yeltenmişler, babalarını da sürekli bir üzüntü ve kedere düşürmüşlerdir. Çünkü içlerindeki haset onları yiyip bitirmiş ve şiddetlenip had safhaya ulaşmıştır. Bk. Fahreddin er-Râzî, Tefsîr-i Kebîr: Mefâtîhu'l-Gayb, çev. Suat Yıldırım vd. (Ankara: Akçağ Yayınları, 1990), 13/170-171; İsmâil Hakkı Bursevî, Rûhu'l-Beyân Tefsiri, çev. Abdullah Öz vd. (İstanbul: Damla Yayınevi, 2012), 4/201. Kur'ân-1 Kerîm'de Ehl-i kitaptan bazılarının müslümanları küfre döndürme arzuları onların psikolojilerindeki hasede bağlanarak hasedin temelde bir duygu ve davranış meselesi olduğu vurgulanmıştır (Mustafa Çağrıcı, "Hased”, Türkiye Diyanet Vakfi İslam Ansiklopedisi (Ankara: TDV Yayınları, 1997), 16/378). Haset haram kılındığı için bu Yahudiler üzerinden örneklendirilmiş̧ir: "Kitap ehlinden birç̧ŏu, hak kendilerine belirdikten dahi, içlerindeki kıskançlıtan ötürü, sizi imanınızdan sonra küfre döndürmek isterler. Siz şimdilik Allah onlar hakkındaki emrini getirinceye kadar affedin, hoşgörün. Şüphesiz Allah gücü her şeye hakkıyla yetendir." (el-Bakara 2/109). Görülmektedir ki haset insan hayatının en güçlü ve en temel dinamiklerinden olan inanç noktasında dahi kişiyi gerçeği bile bile ısrarla bâtıl olanda direnmeye sevk etmektedir.

* "De ki: "Yarattığı şeylerin kötülüğünden, karanlığı çöktüğü zaman gecenin kötülüğünden, düğüumlere üfleyenlerin kötülüğünden, haset ettiği zaman hasetçinin kötülüğünden, sabah aydınliğının Rabbine sığınırım.” (elFelâk 113/1-5). 
dile getirilmiştir. Hasetçinin şerri, sûrede zikredilen diğer kötülükler arasında en y1k1c1 olduğu için bu sûre haset ayeti ile bitmiştir. ${ }^{71}$ İbn Kayyım'1n ${ }^{72}$ ifadesiyle hasetçi kimse eli ve diliyle herhangi bir kimseye kötülük etmese bile, onun hasedi nefsinden ve gözünden başlayıp haset edilene ulaşan bir şerdir. Öfke dolu bir psikolojiye sahip kimsenin nefsi, bakışıyla bile etki eder. Bazen de haset yalnızca bireyin psikolojisinde gerçekleşir ve haset ettiği kimse bir anda aklına geldiğinde kalbinden haset ateşi saçılır ve haset okları ona yönelir. Haset edilen birey haset edenden uzakta dahi olsa bundan etkilenir. Böyle bir durumda bile haset kişiyi bu kadar etkisi altına alabiliyorken, haset etmeye neden olacak eylem açıkça görüldüğünde etkinin çok daha büyük olacağını hemen söylememiz gerekir. Bu yüzden ayette yer alan haset ettiği zaman kaydı oldukça dikkate değerdir. Haset eden kimse hasedini harekete geçirdiğinde muhatabının sahip olduğu güzelliği yok etmek için çaba sarf eden bir kişi hâline gelir. Özellikle de kin, öfke ve düşmanlık duyguları ile haset ettiği kimseye yöneldiğinde hasedin yıkıcılığı çok daha büyük olur. ${ }^{73}$ Çünkü o, zulmeder, her türlü hileyi düşünür, büyüye başvurur, merhamet göstermez. Güzellik, kalite ve başarı haset edilende durdukça, haset eden kendini yer bitirir. Bu yüzden haset, önce haset edeni yok eder. Hasetçi kimseye "Arzuladığın şey haset ettiğin kimsede kalsın, sana da istediğin şeyi verelim" denilse bile asla memnun olmaz. Zira aslolan başkasındaki nimetin gitmesidir, kendisine bir şey verilmese bile bundan hoşnut olur. ${ }^{74}$ Dolayısıyla bu kişiler kendilerine iyilik yapanlara bile haset edebilirler. ${ }^{75}$

Yukarıda dinî ve psikolojik açıdan zararlarına işaret ettiğimiz haset, birtakım ahlakî kusurlara ve ahlakî sapmalara yol açabilmektedir. Kişilerarası ilişkilerde dışlayıcı ve yıkıcı tavırların sebebi olan haset duygusu aynı zamanda bireyin Yaratıcı ile olan ilişkilerini de büyük ölçüde bozmaktadır. O’nun iradesini sorgulama ve yargılama yetkisini kendinde gören ve bu iradeden hoşnut olmayan birey hem iç dünyasında hem de diş çevrede aktif bir isyana yönelerek Allah ile bir çatışma içerisine girebilmektedir. Hâlbuki yapılması tavsiye edilen başkasının elindekine göz dikmekten kaçınıp çalışmak, Allah'a yönelmek ve elde etmek istediğimizi O'ndan talep etmektir. Allah'ın kulları arasındaki taksimatına rıza gösterme ve O'ndan râzı olma, hasedin neden olacağı yıkımdan kurtulmayı sağlayacak güvenli bir sı̆̆ınaktır.

Gıpta ise bir kimsenin başkasının sahip olduğu hayır ve nimetin benzerini kendisi için istemesi olarak tanımlanmaktadır. Hasedin aksine bu duyguda başkasında olan nimetin yok olması arzu edilmez. ${ }^{76}$ Gipta bir şeyi beğenme, sevme ve hoşlanma gibi

\footnotetext{
71 Ali Arslan, Büyük Kur'an-ı Kerim Tefsiri (Hülâsâtü't-Tefâsîr) (İstanbul: Arslan Yayınları, ts.), 16/267.

72 İbn Kayyım el-Cevziyye, İbn Kayyim Tefsiri: Bedâi'u't-tefsîr, 4/656.

73 Süleyman Ateş, Yüce Kur'ân'ın Çağdaş Tefsiri (İstanbul: Yeni Ufuk Neşriyat, 1989), 6/3181.

74 Yazır, Hak Dini Kur'ân Dili, 10/172-174.

75 İbn Hazm, Ahlak ve Davranış Tarzları Nefislerdeki Ahlâkî Hastalıkların Tedavisi, çev. Mustafa Çağrıcı (Ankara: TDV Yayınları, 2015), 48.

76 Arslan, Büyük Kur'an-ı Kerim Tefsiri, 267; Süleyman Ateş, İslam Tasavvufu (İstanbul: Yeni Ufuk Neşriyat, 2004), 414; İsfahânî, Erdemli Yol, 261; Kınalızâde Ali Efendi, Ahlâk-ı Alâ̂, haz. Hüseyin Algül (İstanbul:
} 
anlamları içinde barındırmakla beraber ${ }^{77}$ iyilik ve güzelliklerin artmasını temenni etmek anlamına da gelir. ${ }^{78}$ Başkalarının sahip olduğu bir nimetin benzerinin kendisi için de olmasını isteme 'iyilikte yarışma anlamında da kullanılmıştır. ${ }^{79} \mathrm{Gıpta} \mathrm{hasedin}$ aksine insanları olumlu bir rekabet yoluyla toplumun refahını yükseltmeye, bireyin ve toplumun ruh sağlığını korumaya ve geliştirmeye sevk ettiği için İslam alimlerince uygun ve faydalı bir davranış olarak görülmüsstür. Öyle ki bu duygu sahibini iyiliğe sevk etmekte ve bu yüzden de gipta sahibi olanlar takdir edilmektedir. ${ }^{80}$

İfade ettiğimiz gibi İslam kültüründe hasetle mücadele konusunda örnek gösterilebilecek bir duygu olan gıpta, aslı itibarıyla başkasındaki maddi ve manevi güzelliklerin yokluğunu arzulamadan, kişinin kendisi için de talep etmesidir. Hasetteki tek taraflı ve diğerinin aleyhine elde etme arzusunun aksine giptada çift taraflı ve diğerinin lehine de olacak bir kazanım söz konusudur. Başka bir deyişle "onda olmasın bende olsun" arzusu "onda olsun ama bende de olsun" arzusunu içeren daha olumlayıcı ve daha insanî bir anlam kazanır.

\section{Hasedin Nedenleri}

Haset, bireyin kendilik ve benlik algısının olumsuz şekillenmesi sonucu ortaya çıkan çeşitli duygusal durumlar ile alakalıdır. Bu durumda birey haset ettiği kişiden daha aşağı düzeyde kendini konumlandırır. Ben-Ze'ev ${ }^{81}$ haset duygusunun açıklanmasında aşağıllk duygusu ve hak etme faktörlerini zikreder. Haset duygusu aşağılık hissi ve diğerinin hak etmediği iyi talihi ile ilgilidir. Miceli ve Castelfranchi ${ }^{82}$ hasedin oluşmasında etkili olan bazı bileşenleri daha ayrıntılı olarak sıralar: (i) Belirli bir hedef veya hedef sınıfı ile ilgili olarak olumsuz bir karşılaştırma ii) Aşağılık duygusu ve kısmî benlik saygısı kaybı nedeniyle acı çekme iii) Kişinin aşağılık duygusunun üstesinden gelme konusundaki çaresizliği ve umutsuzluk duyguları (iv) Avantajlı tarafa yönelik kötü niyet (v) Son olarak avantajlı tarafın bazı hedeflerine ulaşmamasını dilemektir. Biz de çalışmamızda haset duygusunu büyük ölçüde tetiklediğini düşündügümüz en temel üç faktörü inceleyeceğiz. Bu üç neden hasette oynadıkları temel rol

Tercüman 1001 Temel Eser, ts.), 229; Ebû Abdillah Muhammed b. Ahmed el-Kurtubî, el-Câmi‘ li Ahkâmi'l-Kur'ân, çev. M. Beşir Eryarsoy (ìstanbul: Buruc Yayınları, 1997), 19/478; Ebû Zekeriyyâ Muhyiddin Yahyâ b. Şeref b. Muri en-Nevevî, Riyâzü’s-Sâlihîn, çev.- şerh. M. Yaşar Kandemir vd. (İstanbul: Erkam Yayınları, 2009), 3/360; Ramazan Yazçiçek, Haset (İstanbul: Ekin Yayınları, 2014), 109; Yazır, Hak Dini Kur'ân Dili, 10/173.

77 İbn Kayyım el-Cevziyye, Allah Sevgisi, çev. İshak Emin Aktepe - Ahmet Akbaş (ìstanbul: Karınca \& Polen Yayınları, 2012), 302.

78 Nevevî, Riyâzü's-Sâlihîn, 3/360, 5/559.

79 Râzî, Tefsîr-i Kebî: Mefâtîhu'l-Gayb, 3/324.

80 Ebu'l-Hasen Ali b. Muhammed b. Habib el-Mâverdî, Yüce Hedefler Kitabı, çev. Ahmed Cevdet Efendi (İstanbul: Büyüyen Ay Yayınları: 2013), 524; Nevevî, Riyâzü's-Sâlihîn, 5/105.

81 Ben-Ze'ev, The Subtlety of Emotions, 283.

82 Maria Miceli - Cristiano Castelfranchi, “The Envious Mind”, Cognition and Emotion 21/3 (2007), 470. 
nedeniyle önem ve merkezîliklerini korumaktadırlar.

\subsection{Hak Idddia Etme ve Adaletsizlik}

Hak iddiası, haset ve kıskançlık duygularının çekirdeğini oluşturan ana değişkenlerden biridir. Haset, salt bir arzuyu değil aynı zamanda bir hak iddiasını da ihtiva eder. Başkalarının başarısına yönelik duygularımızın pozitif, negatif veya nötr olup olmadığının belirlenmesinde hak edilebilirliğin göz önünde bulundurulması oldukça önemlidir. Diğerinin üstünlüğünü hak etmediğini düşündügüüüzde, haset, hınç veya öfke duygusunu deneyimlerken, üstünlüğün hak edildiğini düşündügümüzde ise hayranlık duygusunu deneyimleyebiliriz. ${ }^{83}$ Haset, öznenin göreceli aşağılık duygusunu ve bu yoksunluğun hak edilmediğine dair olan inancını içermektedir. Hak etme ile hasedin yoğunluğu arasındaki ilişki pozitif yönlüdür. Aşağıda olma durumunun hak edilmediğine ne kadar çok inanılırsa hasedin yoğunluğu da o kadar büyük olmaktadir. ${ }^{84}$

İnsanlar arasındaki birçok eşitsizliğin kontrol edilemeyen kökenleri ve bu eşitsizliklerin insanların hayatları üzerindeki güçlü etkileri, hasetçi bireyin adaletsizlik algisına dair daha güçlü bir avantaj sağlıyor gibi görünmektedir. ${ }^{85}$ İnsanlar kişisel hak taleplerini ahlakî hak talepleri olarak düşünmeye eğilimlidirler. Hasetçi bireyler genellikle kendi durumlarındaki adaletsizliği, ahlakî alana ait bir durum olarak tanımlayabilirler. Böylece hasetlerini meşrulaştırmaya ve ahlakî adalet normlarına dayanan bir hınç olarak sunmaya çalışırlar. ${ }^{86} \mathrm{Hak}$ iddiası bazen hasedi meşrulaştırma etiketi olarak karşımıza çıkabilmektedir. Bu şekilde hasetçi kendisini doğrulamış olmakta ve hasedine bir geçerlilik ve gerekçe kazandırmaktadır.

Smith ve arkadaşlar ${ }^{87}$ tarafından yapılan bir çalışmada haset ile öznel adaletsizlik ve aşağılık duygusu arasındaki ilişki incelenmiş, öznel adaletsizlik inancının düşmanca duygularla güçlü bir şekilde ilişkili olduğu tespit edilmiştir. Feather ve $\mathrm{McKee}^{88}$ tarafından yapılan bir diğer çalışma, hak etme algısının pozitif ya da negatif duyguların deneyimlenmesinde önemli bir değişken olduğunu ortaya koymuştur. Bireylerin haset ettikleri kişinin imtiyazları hak etmediğine inandıkları takdirde o kimseye karşı düşmanca duygular hissetmeleri olasıdır. Genellikle haset eden bir kişi, haset ettiği kişinin avantajlarını haksızca elde ettiğine inanmaktadır. ${ }^{89}$

83 Ben-Ze'ev, The Subtlety of Emotions, 150.

84 Ben-Ze'ev, "Envy and Inequality”, The Journal of Philosophy 84/11 (1992), 564.

85 Smith, "Envy and the Sense of Injustice", 91.

86 Ben-Ze'ev, The Subtlety of Emotions, 149, 288.

87 Richard H. Smith vd., "Subjective Injustice and Inferiority as Predictors of Hostile and Depressive Feelings in Envy”, Personality and Social Psychology Bulletin 20/6 (1994), 708-710.

88 Norman T. Feather - Ian R. McKee, "Differentiating Emotions in Relation to Deserved or Undeserved Outcomes: A Retrospective Study of Real-life Events", Cognition \& Emotion 23/5 (2009), 962-969.

89 Smith, "Envy and the Sense of Injustice", 93. 
Hak iddiası esas olarak haset eden bireyin şu anki konumu ile hak ettiğini düşündüğü durum arasındaki uyumsuzluktan kaynaklanmaktadır. Birey karşısındaki kimsenin içinde bulunduğu konumu hak ettiğine inanmıyorsa, hasedin çok daha güçlü ve yoğun olma eğiliminde olmasının yanı sıra haset, düşmanca duyguları körüklemekte ve hasedin açıkça temsiline yol açmaktadır.

\subsection{Aşağllık Duygusu}

Hasetteki aşağılık algısının rolü ve bu algının olumsuz kendini değerlendirme ile ilişkisi, haset duygusunu psikolojik bakış açısıyla ele alan birçok yazar tarafından vurgulanmaktadır. ${ }^{90}$ Bilimsel literatür hasedin yoğun bir acı vermesinin nedenlerinden biri olarak aşağılık duygusunu gerekçe göstermektedir. ${ }^{91}$ Haset eden bireylerin temel kaygıları aslında kendi aşağıda olma durumlarına yöneliktir. ${ }^{92}$ Bir kimse haset ettiği kimseyle girdiği rekabetçi başarısızlıktan dolayı kendini aşağıda hissedebilmektedir.93 İnsanlar maddi varlıkları ve beklentileri konusunda da kendilerini aşağıda hissedebilirler. Güvenli olmayan bir araç kullanmak veya ilgi çekici yerlere seyahat edememek, bu firsatlar ve özgürlüğe sahip olan biri karşısında oldukça kötü bir durum olarak gözükmektedir. ${ }^{94}$

Özne ile nesne arasındaki boşluk büyük olduğunda, aşağılık duygusu daha belirginleşmektedir. Ancak bu duygusal açıdan daha az önem taşımaktadır. Öte yandan hafif/küçük eşitsizlik genellikle büyük eşitsizlikten daha fazla duygusal etkiye sahiptir. Haset hak edilmemiş aşağllk duygusu olarak tanımlandığında, hasedin yoğunluğu ile özne-nesne boşluğu arasındaki ilişkinin ne olduğu ilk bakışta anlaşılabilir değildir. Örneğin, meslektaşımızın bir ödül kazandığı durumu ele alalım. Eğer meslektaşımız gerçekten ödülü hak ediyorsa, o zaman aşağılık duygumuz belirgin hâle gelir ve haset duygusunun açığa çıkması muhtemeldir. Şayet meslektaşımız ödülü hak etmiyorsa, aslında ödülü kendimizin alması gerektiğini düşünebiliriz ve bu da hasedi kışkırtabilir. Ancak her iki durumda da hak etmenin yanı sıra aşağılık duygusu da olumsuz duygusal durumun ortaya çıkmasında rol oynamaktadır. ${ }^{95}$ Zira insanlara aşağıda olma durumlarını ve hayal kırıklıklarını hatırlatan deneyimler hasede yatkınlığı arttırabilmektedir. ${ }^{96}$

Aşağılık duygusu genelde aynı ortamda bulunduğumuz, iletişim hâlinde olduğumuz yahut kendimize rakip olarak gördüğümüz yakın çevremizdeki kişilerin elde ettiği herhangi bir başarı karşısında ortaya çıkan ve aynı zamanda bireye değersizlik

\footnotetext{
90 Miceli - Castelfranchi, “The Envious Mind”, 452.

91 Powell, vd., "Schadenfreude Caused by An Envied Person's Pain”, 151.

92 Ben-Ze'ev, The Subtlety of Emotions, 305.

93 Hacker, The Passions: A Study of Human Nature, 229.

94 Alicke - Zell, "Social Comparison and Envy”, 83.

95 Ben-Ze'ev, The Subtlety of Emotions, 307.

96 Alicke - Zell, "Social Comparison and Envy", 75.
} 
ile yetersizlik hislerinin eşlik ettiği bir duygu durum hâlidir. Çünkü bireyin kendisinin olmasını arzuladığı, büyük bir özlemle elde etmek istediği şeyleri başkasının elde ettiğini görmesi benlik saygısına vurulmuş bir darbe niteliğindedir. Bireyin kendisi için önemli olan birinin başarısı, onun kendisini ezilmiş, aşağıda, değersiz, başarısız, kabiliyetleri sınırlı biri olarak düşünmesine ve hissetmesine neden olmaktadır. Gittikçe büyüyen bu negatif his ve düşünceler, bireyi aynı zamanda bir çaresizliğe de sürükleyebilmektedir. Bu, bireyin kendi benliğinin gereksinimlerinin doyurulmasında engelleyici bir işleve sahiptir. Bireyin kendi gelişimi için harcayabileceği enerjinin minimum seviyede kalmasına hatta yoksullaşmasına yol açmaktadır.

\subsection{Sosyal Karşılaștırma}

"Bireyin kendisi hakkında bir fikir edinebilmek veya sahip olduğu fikri korumak için kendini diğerleriyle karşılaştırma süreci" ${ }^{97}$ olarak tanımlanan sosyal karşılaştırmanın insan hayatında çok önemli bir rolü olduğu açıkça görülmektedir. Sosyal karşlaştırma, kişi için önemli olan bir konuda kendisinden üstün olan bir diğer kişinin varlığı ile başlar. ${ }^{98}$ Bu kişi genellikle sosyal statü bakımından haset eden bireyle aynı ya da ondan biraz daha yüksek statüde olan kimsedir. ${ }^{99}$ Kendimizi yaş, cinsiyet, meslek veya diğer özellikler açısından bize en yakın olan kişilerle karşılaştırma olasılığımız daha yüksektir. ${ }^{100}$ Çünkü haset genelde tipik olarak bireyin duygusal çevresine, yani onun için duygusal öneme sahip kişilere hitap eder. Herkes ve her şey karşılaştırma konusu olmaz. ${ }^{101} \mathrm{Bu}$ yüzden bireyin bizden aşağıda olma derecesi ile hasedin yoğunluğu arasında pozitif bir ilişkiye genellikle rastlanmaz. ${ }^{102}$ Ancak gerçek hayatta ast-üst ilişkisi eş zamanlı olarak ve duruma göre değişkenlik gösterebilir. Örneğin, genç bireyler yaşlılara zenginlik ve güçleri için haset ederken, yaşlilar da gençlere sağlıkları ve güzel görünümlerinden dolayı haset edebilir. Balık tutmaya devam eden işsiz gençler, servetinden dolayı banka müdürüne haset edebilir ancak banka müdürü de balık tutma özgürlüğü nedeniyle işsiz gençlere haset edebilir. Haset gruplar, sınıflar ve tüm toplumlar arasında da etkili olabilir. Yoksul bireyler zenginlere tümüyle haset edebilir. Yarışmalarda kaybedenler genel olarak kazananlara haset ederler. ${ }^{103}$

\footnotetext{
97 Nuri Bilgin, Sosyal Psikoloji Sözlüğü: Kavramlar, Yaklaşımlar (İstanbul: Bağlam Yayıncılık, 2003), 348.

98 Parrott, "The Emotional Experience of Envy and Jealousy", 12.

99 Ben-Ze'ev, "Envy and Jealousy”, 503; Belk, "Benign Envy”, 121; Sara Protasi, “Varieties of Envy”, Philosophical Psychology 29/4 (2016), 537.

${ }^{100}$ Emmanuel Habimana - Line Massé, "Envy Manifestations and Personality Disorders", European Psychiatry 15 (2000), 16.

101 Ben-Ze'ev, The Subtlety of Emotions, 285.

102 Aaron Ben-Ze'ev, “Are Envy, Anger, and Resentment Moral Emotions?" Philosophical Explorations 5/2 (2002), 151

103 Clanton, "Jealousy and Envy", 425.
} 
Haset duygusunda rahatsızlık veren şey her türlü yoksunluktan ziyade göreceli yoksunluktur. Zengin bir kişi, kendisinden daha zengin olan başka birine haset edebilirken, güzel bir film yıldızı başka bir yıldızın güzelliğine haset edebilmektedir. ${ }^{104}$ Hasetçinin karşılaştırması, belirli ve sınırlı bir hedeften çok, daha soyut hedeflere kadar herhangi bir düzeyde gerçekleşebilir. Kişi kendini sosyal prestij veya yaşamda mutluluk gibi genel ve soyut bir hedefle kiyaslayabilir. ${ }^{105}$

Hasette kritik rol sosyal karşılaştırma ile oynanır. Olumsuz bir karşılaştırmanın sonucu olarak, hasetçinin kendine örtük bir biçimde kendisine sürekli "Niçin o, ben değil?" veya "Bu niçin böyle oldu?" gibi sorular sorduğu varsayılabilir. ${ }^{106}$ Haset edilen kişi ile kıyas devreye girdiğinde 'Onda var, bende yok' düşüncesi bireyin zihninde saplantı hâlini alır. Çoğunlukla kıyaslanan kişi daha üstünmüş gibi algılanır. Bunun sonucunda birey kendisini yetersiz, eksik, çaresiz, başarısız hisseder. Özgüveni ve özbeğenisi deprem geçirmişçesine sarsılır. ${ }^{107} \mathrm{Bu}$ durum, bireyin zihnî özgürlüğünü kendi eliyle (kasıtlı ya da elinde olmayarak) kısıtlaması anlamına gelir. Başka bir ifadeyle zihinsel bakımdan kısmî bir tükenişi ifade eder.

Hasette yukarı doğru karşılaştırma sürecine itirazlar ve sorular da eklenerek, hasedin daha görünür hâle gelmeye başlandığı söylenebilir. Bu bağlamda 'Onda var, ben de niye yok?' sorusu hasedi tutuşturan ilk adım, memnuniyetsizliğin ilk tezahürüdür. Bu soru içselleştikçe ve buna bağlı olarak karşılaştırmanın olumsuz seyri sürdükçe öteki, birey için tehdit edici bir varlık hâline gelebilmektedir. Çünkü kendisiyle benzer konum ve altyapıda olan kimse bir bakıma ayna işlevi görür. Kişi kendisini karşı tarafın varlığı üzerinden bir değerlendirmeye tabi tutmaktadır. Diğerinin kazanımları ve elde ettikleri onun için bir ölçü ve gösterge olmuştur. Bu iyelikler birey için uyarıcı bir etkiye sahiptir. Dolayısıyla bireyin hem kendi hem de diğeri ile bir çatışma içerisine girmesi kaçınılmazdır. Olumsuz karşılaştırma sonucu meydana ç1kan bu çatışma kişiyi ruhî bunalımlara ve kötücül davranışlara sevk edebilir. Sosyal kıyaslamanın kişide oluşturduğu kaygı nispetinde bireyin haset yoğunluğu da değişkenlik arz eder.

\section{Haset ve Ruh Sağlı̆̆1}

Haset duygusunun insan davranışları üzerinde güçlü bir etkisi bulunmaktadır. Ac1 verici ve negatif duygular ile saldırgan davranışlarla ilişkilendirilen bu duyguya kötü niyet, açgözlülük ve aşağılık duygusu eşlik eder. ${ }^{108}$ Yokluk, boşluk, eksiklik, yok-

\footnotetext{
104 Ben-Ze'ev, "Envy and Inequality", 555; a. mlf., The Subtlety of Emotions, 284; “Are Envy, Anger, and Resentment Moral Emotions?”, 150.

105 Miceli - Castelfranchi, “The Envious Mind”, 455.

106 Miceli - Castelfranchi, “The Envious Mind”, 458.

107 Navaro, Haset ve Rekabet Kendi Kuyruğunu Yiyen Yılan, 27.

108 Vidaillet, Workplace Envy, 19-22.
} 
sunluk ve şiddetli bir hoşnutsuzluk/hazsızlık (unpleasure) bu duyguyla yakından ilgili olan kavramsal ve ampirik bağıntılardır. ${ }^{109}$ Parrott'a $^{110}$ göre haset asgari altı alt duygusal tecrübeyi içinde barındırır. Bunlar özlem/hasret, aşă̆llık duygusu, belirli bir kişi/grubun üstünlüğünden ya da şartların veya kaderin adaletsizliğinden kaynaklanan hınç duygusu, kötü niyetten kaynaklanan suçluluk ve hayranlıktır. Suçluluk duygusunun ortaya çıkması için haset eden bireyin kötücül düşüncelerinin yanlış veya günah olduğunu fark etmesi gerekir. Kökenini ilişkilerin doğasında var olan utanç, kaygı ve çaresizlik duygularından alan haset duygusu ${ }^{111}$ yetersizlik, küçük düşme ve kendine saygı eksikliği nedeniyle bireyde utanç meydana getirir ve genellikle bu duygular hızla öfke, saldırganlık veya kendine zarar verici davranışlara dönüşür. ${ }^{112}$ Kişilerarası çatışmalar, düşük benlik saygısı, depresyon, kaygı ve haset edilen kişilere veya onların mallarına yönelik saldırganlık gibi çeşitli uyumsuzluk biçimlerinin yanı sıra kundakçılık, vandalizm, saldırı ve hatta cinayet gibi cezaî davranışlarla bile ilişkilendirilmiştir. ${ }^{113}$ Haset ve kıskançlığın en can alıcı noktası eksiklik, kıyaslama sonucu oluşan küçük düşmüşlük ve utanç duygusudur. Kişi bu duygulardan kurtulabilmek ya da çektiği acının intikamını almak için diğer bireye benzer düzeyde acı çektirme, ona zarar verme gibi istekler duyar. ${ }^{114} \mathrm{Bu}$ yüzden hasedin utanç verici olduğu hissedildiğinde ve haset duyan birinin hasedinin açığa çıkmasından korkulduğunda, bu duygu daha tehlikeli bir hâle bürünebilir. ${ }^{115}$

Sosyal karşılaştırma ve hasedin neden olduğu en güçlü dürtü intikamdır. İntikam duyguları, kaybetmenin acısını ve ezikliğini birazcık da olsa dindiren sanal bir merheme benzer. Bu duygunun hazzını yaşamak adeta kişilik gururunu restore ediyor gibi iş görür. ${ }^{116}$ Hasedin düşmanca duygularla birleştiği hâllerde vicdan, haz ve saldırganlık duygularının denetimi altına geçer ve bireydeki sevgi, merhamet ve şükran duygularını söndürebilir. Bazı kişilik rahatsızlıklarında da haset önemli bir öncül olarak ortaya çıkmaktadır. Örneğin, narsisistik kişilik bozukluğu olan hastaların klinik çalışmaları, saldırganlığın esas duygusal dışavurumu olarak bilinçli veya bilinçsiz hasedin göze çarpan bir faktör olduğunu ortaya koymaktadır. ${ }^{117}$ Cooper $^{118}$ narsisistikmazoşist karakterin özelliklerinden birinin sürekli bir haset duygusu olduğunu ifade eder. Öç durumları ile kin ve intikam hezeyanları, genelde narsisistik yaralanmalar

\footnotetext{
109 Ninivaggi, Envy Theory: Perspectives on the Psychology of Envy, 39.

110 Parrott, W. Gerrod. "The Emotional Experience of Envy and Jealousy", 13, 14.

111 Kilborne, Utanç ve Haset: Görünüm Kaygısı ve Kem Göz, 4.

112 Navaro - Schwartzberg, "Conclusions and Therapeutic Implications", 205.

113 Habimana - Massé, "Envy Manifestations and Personality Disorders”, 15.

114 Navaro, Haset ve Rekabet Kendi Kuyruğunu Yiyen Yılan, 28.

115 Kilborne, Utanç ve Haset: Görünüm Kaygısı ve Kem Göz, 30.

116 Navaro, Haset ve Rekabet Kendi Kuyruğunu Yiyen Yılan, 85.

117 Otto Kernberg, Aggressivity, Narcissism, and Self-destructiveness in the Psychotherapeutic Relationship: New Developments in the Psychopathology and Psychotherapy of Severe Personality Disorders (New Heaven and London: Yale University Press, 2004), 34.

118 Arnold M. Cooper, “The Narcissistic-masochistic Character”, Psychiatric Annals 39/10 (2009),912.
} 
sonucu oluşur. ${ }^{119}$ Hasedin belirgin temalarından olan açgözlülük, kötü niyet, yoksunluk, utanç, intikam, göz dikme, bireyin psikolojik ve öznel iyi oluş hâlini olumsuz yönde etkileyen, pozitif duyguların bilinç düzeyine çıkamamasının sonucu aşırı reaksiyoner bir tavra neden olabilen duygulardır. Birey duygularını düzenlemekte ve kontrol altına almakta zorlanır. Çeşitli duygusal yüklemeler bireyin suçluluk, pişmanlık, utanç gibi duygular hissetmesine neden olarak bireyin kendilik algısı ve kendilik değerine zarar verebilmektedir. Saldırganlık dürtüsüyle birlikte zarar verme ve intikam alma arzusuna evrilen haset duygusu, bireyin içsel otoritesini sağlamasının önünde büyük bir engel teşkil edebilmektedir.

Duygular dengesizleştiğinde yatağı kurumuş veya sel gelip duvarlarını yıkmış ırmak gibi, bireye ve çevresine zarar vermeye başlar ve uyumsuz durumlara neden olur. ${ }^{120}$ Haset de yoğunluğu belli bir düzeye geldiğinde zehirli bir hâle dönüşen duygulardandır. ${ }^{121}$ Bu duygu daha uzun süre devam ettiğinde kişinin duygu yönetimini ve ilişkileri idare etme yeteneğini sınırlandırır; bireyi duygusuzlaştırır ve bireyin gerçeklikle ilişki kurmasını azaltabilir. Yoğun haset duygusu bireyde uyumsuz davranış örüntülerine neden olabilmekte, hasetçi birey şiddetli duygusal ve fiziksel tepkiler göstermesine yol açabilmektedir. Ninivaggi'ye ${ }^{122}$ göre haset zihinsel işleyişte zayıflık oluşturur. Duygusal yaratıcılığı engeller ve doğru düşünme için gelişen kapasitenin önüne set çeker. Haset sadece ideal olanı bozmakla kalmaz, negatif yaratıcllık için harekete geçer.

Bireyleri hatta toplumları tahrip edebilen düşmanlık ve saldırganlık duygularını istiâb ettiği için hasedin tehlikeli bir duygu -en azından bilinçaltında, evrensel olarak korkulan- ve bütün insanları etkileyen bir fenomen olduğu söylenebilir. ${ }^{123}$ İçsel uyumunu ve iç bütünlüğünü sağlayamamış, kendisiyle barışık olmayan birey, sürekli yaşadığı gerilim ve çatışma hâliyle birlikte, başkalarının sahip olduğu şeyleri değersizleştirmeye, zarar vermeye ve yok etmeye çalışır. Özellikle de acı çekme seviyesi yükseldikçe intikam ve düşmanlık duyguları da buna bağlı olarak yükselmektedir. Haset sinsi bir virüs gibi bireyin duygu, düşünce ve tutumlarına sirayet eder, ona tutunur ve onu birakmaz. Saldırganlık duygusunun aktif olmasina neden olur ve bireyin kontrolsüz davranışlar sergilemesine yol açar. Dolayısıyla haset, etkileri itibarıyla büyük ölçüde olumsuzluğu öncelemektedir. Bireysel ve toplumsal bir deformasyona yol açabilmekte, keyfî birtakım davranışlara neden olmaktadır. Bu minvalde haset ruh sağlığını olumsuz etkileyen çok güçlü bir duygu olarak karşımıza çıkmaktadır. Ancak -tüm zikredilenlere rağmen- haset, bir iç hesaplaşma ile kendini yeniden tanıma ve algılama sürecinin bir parçası hâline de gelebilir. Bu ilerleme, bireyin öznel

\footnotetext{
119 Navaro, Haset ve Rekabet Kendi Kuyruğunu Yiyen Yılan, 85.

120 İbrahim Gürses, Dindarlık ve Kişilik (Bursa: Emin Yayınları, 2010), 49.

121 Epstein, Envy: The Seven Deadly Sins, 93.

122 Ninivaggi, Envy Theory: Perspectives on the Psychology of Envy, 80.

123 Foster, “The Anatomy of Envy: A Study in Symbolic Behaviour", 186.
} 
ve psikolojik iyi oluş hâlini pozitif yönde etkileyerek haset duygusunu pasifize etmeye yeterli ölçüde katkı sağlayabilir. Böylece yeni iyi oluşlara ivmelendirebilir, benlik saygısının muhafaza edilmesine katkı sağlayabilir, yeni bir ruh hâlinin inşasına firsat verebilir. Dünkü ben yepyeni bir ben olarak doğabilir.

\section{Hasetle Başa Çıkma}

Psikolojik bakış açısına göre haset duygusunu tamamen yok etmek yerine, şiddetini ve etkisini azaltmak ya da gipta, imrenme gibi başka bir duyguya dönüştürerek bireyin benlik gelişimine katkıda bulunması hedeflenir. Bu yüzden haset ve hasetle ilişkili duygulardan kaynaklanan bazı davranışların altında yatan koşulları kınamak, bu tür duyguların doğrudan kınamaktan çok daha rasyonel bir tutumdur. Haset duygusu bazı yararlı sosyal işlevlere sahip olduğu için bu duyguyu patolojik olarak görmek doğru değildir. ${ }^{124}$

Aşağıda haset duygusuyla başa çıkabilmek için faydalı olabilecek bazı önerilere işaret edilmiştir.

(i) Öncelikle haset duygusunun farkında olmak, bu duyguyla başa çıkmada ilk adımı olarak görülebilir. Bu farkındalık haset eden kimsenin saldırganlığını azaltmasına ve özne-nesne arasındaki boşluğu kapatmak için alternatif çözümler aramasına yardımcı olabilir. Haset duygusunun farkına varmak ve onu kabullenmek içsel kontrolü güçlendirir. ${ }^{125}$

(ii) Duygusal farkındalık elde etmek ${ }^{126}$,yeterli derecede sevgi ve şefkat duygusuna sahip olmak, samimiyet ve şükran hissedebilmek, rakibe olan haset hissini dengede tutabilmek ve kendi varlı̆̆ımızın bilincinde olmak gibi faktörler haset duygusunu kontrol altına almada temel alternatifler olarak görülebilir. ${ }^{127}$

(iii) Üretkenlik, haset duygusunun azalmasında önemli bir faktördür. Haset edenlerin üretkenlik için çaba sarf etmeleri onları haset duygusundan uzaklaştırır. İşlevsel ve etkin bir üretkenlik bireye kendisini daha yetenekli hissettireceği için gıpta duygusunun ortaya çıkma ihtimali oldukça yüksektir. ${ }^{128}$

124 Ben-Ze'ev, "Envy and Jealousy", 515; a. mlf., The Subtlety of Emotions, 323, 324.

125 Avi Berman, "Envy at the Crossroads Between Destruction, Self-actualization and Avoidance", Envy, Competition and Gender: Theory, Clinical Applications and Group Work, ed. Leyla Navaro -Sharan L. Scwartzberg (New York, NY: Routledge, 2007), 22.

126 Quintanilla-Jensen de López, "The Niche of Envy: Conceptualization, Coping Strategies, and the Ontogenesis of Envy in Cultural Psychology", 85.

127 Joseph, "Envy in Everyday Life", 22.

128 Avi Berman, "Envy and Generativity: Owning Inner Resources", Envy, Competition and Gender: Theory, Clinical Applications and Group Work, ed. Leyla Navaro - Sharan L. Scwartzberg (New York, NY: Routledge, 2007), 92. 
(iv) Hasetle başa çıkmanın bir diğer yolu da kişinin kendi lehine olacak şekilde karşılaştırmalar yapmasıdır. Diğerlerinden daha iyi olduğumuza dair bir yargı, yıkıcı hasetle baş edebilmenin bir yolu olarak görülebilir. ${ }^{129}$ Başka bir deyişle olumsuz karşılaştırmalar üzerinde durmamak ve haksızlığa uğramış kişi hissine karşı kapılmamak gerekir. ${ }^{130}$

v) Arzulanan bazı şeylerin iyilikten ziyade zarar verici olduğunun ve mutluluk sağlamayacağının farkında olmakla haset duygusu törpülenebilir. Zenginlik veya şöhretin hakiki bir mutluluk sağlamadığına inanmak, zengin veya ünlü kimselere haset etmeyi engelleyici bir tutumdur. ${ }^{131}$

vi) Bireyler arasındaki zenginlik, statü, güç gibi farklılıklar şans, Allah'ın takdiri ve sıkı bir çalışmanın sonucu olarak rasyonelleştirilirse haset duygusunda azalma görülür. ${ }^{132}$

vii) Duygusal patlamaları kontrol altına almak, günlük rutinleri sürdürmek veya istenilen nesnenin, niteliğin ya da ilişkinin önemini yeniden değerlendirmek haset ve kıskançlıkla başa çıkmada etkili stratejilerdir. Bireyin kendi özellikleri hakkında pozitif düşünmeyi öğrenmesi haset ve kıskançlığın yoğun öfke üretmesini veya depresyona dönüşmesini önleyici bir yoldur. ${ }^{133}$

İslam ahlak düşüncesinde de haset duygusunu tamamen yok etmek gibi bir amaç ortaya koyulmaz. Birey kendinde var olan ve kendi aleyhine ve şerrine çalışan güçlerle mücadele etmekle sorumludur ve ancak böyle yaparak olgunluğa ulaşabilir, kendini gerçekleştirebilir. Eğer birey başkasına haset etmeyi hoş görmüyor ve onunla mücadele ediyorsa, bu duygudan uzak durmak istiyorsa, bu kötü duygu ve düşüncenin bireye zarar vermesi beklenemez. Çünkü bu kötücül duygular insan bütünlüğünden bağımsız davranış ortaya koyma gücüne sahip değildir.

Çoğu İslam düşünürü hasedin tedavisinde başarı oranını arttıran etkenin hasedin zararlarını bilme ve idrak etme gerekliliği olduğunu ifade ederler. Onlar da genel olarak hasetten kurtulmak için bilişsel ve davranışsal yöntemleri önerirler. ${ }^{134}$ Bilişsel açıdan haset duygusuyla mücadele etmenin en kestirme yolu, haset edenin hasedinin dünyada ve ahirette kendisine zarar vereceğini, haset ettiği kimseye ise faydalı

129 Lazarus - Lazarus, Passion and Reason: Making Sense of Our Emotions, 32.

130 Kets de Vries, Sex, Money, Happiness, and Death: The Quest for Authenticity, 147.

131 Lazarus - Lazarus, Passion and Reason: Making Sense of Our Emotions, 34.

132 Clanton, "Jealousy and Envy", 440.

133 Peter Salovey-Judith Rodin, “Coping with Envy and Jealousy”, Journal of Social and Clinical Psychology 7/1 (1988), 27-31.

134 Râzî, Tefsîr-i Kebîr: Mefâtîhu'l-Gayb, 3/334-337, Ebû Hâmid Muhammed b. Muhammed el-Gazâlî, İhyâ-i 'Ulûmi'd-Dîn, çev. Ahmet Serdaroğlu (İstanbul: Bedir Yayınları, 2019), 563-570; Hâris b. Esed elMuhâsibî, er-Riâye: Nefs Muhasebesinin Temelleri, çev. Şahin Filiz - Hülya Küçük (İstanbul: İnsan Yayınları, 2011), 567; Mâverdî, Yüce Hedefler Kitabı, 528. 
olacağını bilmektir. Çünkü haset eden kimse günlük yaşantısında sürekli üzüntü, kayg1 ve gerginlik üretir. Bu durum kronik stres durumlarına ve somatizasyonlara yol açar. Dolayısıyla onun için dingin ve sükûna ermiş bir ruhsal dünya mümkün görünmemektedir. Ahirette ise haset ettiği kimsenin günahlarını üstlenmek durumunda kalacaktır. Zira davranışa dökülmüş haset İslam ahlak düşüncesinde kul hakkı olarak değerlendirilmektedir. Bu duyguyla davranışsal olarak başa çıkmak için haset duygusunun tersi davranışlar sergileme iradesi göstermek terapötik bir etkiye sahiptir. Haset ettiğimiz kimseyi takdir etmeyi, onu övmeyi başarabilmek başa çıkma yöntemi olarak önerilir. Bu yönteme İslam düşüncesinde "amelî ilaç" da denir. ${ }^{135}$

Hasetle mücadele sadece hasetle gerçekleştirilen bir mücadele değildir. Onunla mücadele ederken, birey aynı zamanda bu duygunun kardeşleri durumunda olan kibir, kendini beğenme, şiddetli hırs gibi zehirli duygu ve düşüncelerle de mücadele etmektedir. Dolayısıyla bu duyguyla mücadele etmek, psikofizik gücü bir noktada toplamayı, büyük bir irade ortaya koymayı gerekli kılar. Bu duyguyla mücadele ederken, dini öğretilerden yararlanmak, bireyin mücadele gücünü arttırıcı bir fonksiyon icra eder. Bu sebeple hasetle mücadele etmek için Allah'a güçlü bir bağla bağlanmak, onun takdirine boyun eğmek, başkalarının da Allah katında bizim gibi değerli olduğunun bilincinde olmak gerekir. Ancak böyle yaparak, bu duyguyla mücadele kazanılabilir. Zira Allah'a güçlü bir bağ ile bağlanmak ve ona teslim olmak haset ve haset gibi kötücül duygu ve düşüncelere karşı bir antivirüs programı gibi iş görmektedir.

\section{Sonuç}

Haset, tabiî bir duygu olarak başkasında olanı elde etmeye yönelik bir iç çekiş, bir hasret ve şiddetli bir arzudur. Üzüntü, öfke, düşmanlık, hınç, aşağılık duygusu gibi bireyin ruhsal ve ahlakî gelişimini yerine göre engelleyen bazen yıkan duygularla ilintili olan haset, çift kutuplu doğası itibarıyla imrenme, gıpta gibi duygulara dönüşerek bireyin motivasyonunu arttırıcı, onu harekete geçirici psikolojik bir zemine de sahiptir. Bu bakımdan haset bireyde ya bir dönüşüm ya da bir parçalanmanın dinamiği olarak iş görebilir.

Deneyimlenme türüne bağlı olarak hasedin birey üzerindeki etkileri büyük ölçüde farklılık göstermektedir. Hasedi yaşantılayan kimsede negatif duyguların tesiriyle diğerine yönelik birtakım duygusal değişiklikler, düşünce bozuklukları ve ölçüsüz davranışlar görülebilir. Hasette "onun değil benim olsun" anlayışı benimsendiği için, istenen şey elde edilemediğinde düşmanlık, kin, nefret gibi hislerin bireyin duygusal dünyasında baskın hâl

e gelmesiyle sosyal ve insanî açıdan onaylanmayan bir yol takip edilir. Bunun yanında gıpta deneyimi büyük ölçüde olumlayıcı, gizil güçlerin açığa çıkmasında etkili ve bireye kolay ve iyi yoldan bir özdeşleşme imkânı sağlar.

135 Gazâlî, Kimyâa-i Saâdet, çev. A. Faruk Meyan (İstanbul: Bedir Yayınları, 1990), 471. 
İnsanın psikolojik bütünlüğünde etkin olan haset duygusu, haset eden bireyin doğru davranışlar sergilemesine engel olur. O kimse psikolojik bütünlük, iç uyum, denge ve ahengini kaybeder. Ancak hasedi tamamen ortadan kaldırmaya çalışmak gibi bir çabanın yersiz ve sonuçsuz kalacağı aşikardır. Hasetten kurtulmak için yapı kazanmış bir ahlakın kişiliğe yerleştirilmesi ve hasedin sadece yıkıcı taraflarına odaklanmayıp onun inşa edici ve motive edici yönünü de dışarıda bırakmayan bir anlayış gereklidir. İyileştirici duygulardan olan sevgi, şefkat, merhamet, affedicilik, empati, minnettarlık, kardeşlik gibi duyguları güçlendirmek önemli bir adım olarak görülebilir. Güçlü bir kişiliğe sahip olmak -olumlu ve güçlü yanlarının farkında olmanın yanı sıra zayıf yönlerini de görme, kabul etme ve bunları geliştirme yönünde çaba gösterme, kendisiyle barışı olma, sıkıntılar ve krizler karşısında başa çıkma yeteneğinin gelişmiş olması- hasedin ruh sağlığı üzerindeki bozucu etkilerini zayıflatmakta, böylece bireyin kendini gerçekleştirmesini ve ilerlemesini ilke edinmesini mümkün hâle getirmektedir. Öte yandan anlamlı bir hayat yaşama, değer üretebilme, kaygı ve endişe düzeyini azaltmakta; sahici bir kendilik algısı ve varlık tasavvuru sağlayarak bireyin bilişsel şemalarını doğru düzenlemesine katkıda bulunmaktadir.

Yazar Katkı Oranları / Author Contributions: Yazar 1: \% 50. Yazar 2: \% 50.

Çıkar Çatışması / Conflict of Interest: Yazarlar çıkar çatışması olmadığını beyan etmiştir. / The authors declared that there is no conflict of interest.

Finansal Destek / Grant Support: Yazarlar bu çalışma için finansal destek almadıklarını beyan etmiştir. / The authors declared that this study has received no financial support. 


\section{Kaynakça}

Abduh, Muhammed - Rızâ, Muhammed Reşîd. Menâr Tefsiri: Tefsiru'l-Kur'an-i'l-Hakîm. çev. Mehmet Erdoğan vd. 14 Cilt. İstanbul: Ekin Yayınları, 2011.

Alicke, Mark. D.- Zell, Ethan. "Social Comparison and Envy". Series in Affective Science. Envy: Theory and Research. ed. Richard H. Smith. 73-93. New York: Oxford University Press, 2008. https://doi.org/10.1093/acprof:oso/9780195327953.003.0005

Arslan, Ali. Büyük Kur'an-ı Kerim Tefsiri (Hülâsâtü’t-Tefâsîr). 16 Cilt. İstanbul: Arslan Yayınları, ts.

Ateş, Süleyman. Yüce Kur'ân'ın Çağdaş Tefsiri. 12 Cilt. İstanbul: Yeni Ufuk Neşriyat, 1989.

Ateş, Süleyman. İslam Tasavvufu. İstanbul: Yeni Ufuk Neşriyat, 4. Basım, 2004.

Belk, Russell. “Benign Envy”. AMS Review 1 (2011), 117-134. doi:10.1007/ s13162-0110018-X

Ben-Ze'ev, Aaron. “Envy and Jealousy”. Canadian Journal of Philosophy 20/4 (1990), 487516. https://doi.org/10.1080/00455091.1990.10716502

Ben-Ze'ev, Aaron. “Envy and Inequality”. The Journal of Philosophy 84/11 (1992), 551581. https://doi.org/10.2307/2941056

Ben-Ze'ev, Aaron. “Pleasure at Another's Misfortune”. Iyyun, The Jerusalem Philosophical Quarterly 41 (1992), 41-61.

Ben-Ze'ev, Aaron. The Subtlety of Emotions. Cambridge, MA: MIT Press, 2001.

Ben-Ze'ev, Aaron “Are Envy, Anger, and Resentment Moral Emotions?" Philosophical Explorations 5/2 (2002), 148-154. https://doi.org/10.1080/10002002058538728

Berman, Avi. "Envy at the Crossroads Between Destruction, Self-actualization and Avoidance". Envy, Competition and Gender: Theory, Clinical Applications and Group Work. ed. Leyla Navaro -Sharan L. Scwartzberg. 15-30. New York, NY: Routledge, 2007.

Berman, Avi. "Envy and Generativity: Owning Inner Resources". Envy, Competition and Gender: Theory, Clinical Applications and Group Work. ed. Leyla Navaro -Sharan L. Scwartzberg. 85-102. New York, NY: Routledge, 2007.

Bilgin, Nuri. Sosyal Psikoloji Sözlüğü Kavramlar Yaklaşımlar. İstanbul: Bağlam, 2003.

Brigham, Nancy. L vd. "The Roles of Invidious Comparisons and Deservingness in Sympathy and Schadenfreude". Basic and Applied Social Psychology 19/3 (1997), 363-380. https://doi.org/10.1207/15324839751037011

Bursevî, İsmâil Hakkı. Rûhu'l-Beyân Tefsiri. Çev. Abdullah Öz vd. 10 Cilt. İstanbul: Damla Yayınevi, 8. Basım, 2012. 
Clanton, Gordon. "Jealousy and Envy”. Handbook of the sociology of emotions. ed. Jan. E. Stets - Jonathan. H. Turner. 410-442. New York: Springer, 2006.

Cooper, Arnold M. “The Narcissistic-masochistic Character”. Psychiatric Annals 39/10 (2009), 904-912. doi: 10.3928/00485718-20090924-02

Cowan-Jenssen, Sue. "Envy: Everyday and Everywhere". Psychotherapy and Politics International 9/1 (2011), 43-51. https://doi.org/10.1002/ppi.231

Crusius, Jan - Lange Jens. "What Catches the Envious Eye? Attentional Biases within Malicious and Benign Envy". Journal of Experimental Social Psychology 55 (2014), 111. https://doi.org/10.1016/j.jesp.2014.05.007

Crusius, Jan vd., "Envy: An Adversarial Review and Comparison of Two Competing Views". Emotion Review (2019), 1-19. https://doi.org/10.1177/1754073919873131

Çağrıc1, Mustafa. "Hased”. Türkiye Diyanet Vakfi İslam Ansiklopedisi. 16/378-380. Ankara: TDV Yayınları, 1997.

Davidson, William L. "Envy and Emulation", Encylopedia of Religion and Ethics. ed. James Hastings. 12 Cilt. Edinburgh: T\&T Clark, 1908-1927.

Delpierre, Guy. Kıskançlık. çev. Halis Özgü. İstanbul: Özgü Yayınevi, 1967.

Epstein, Joseph. Envy: The Seven Deadly Sins. New York: Oxford University Press, 2003.

Erzi, Seda. Başkasının Zararına Sevinme-Schadenfreude. Ankara: Nobel Bilimsel Eserler, 2019.

Erzi, Seda. "Yardım Davranışlarının Schadenfreude, Benlik Saygısı ve Benlik Tehdit Algısı Bakımından İncelenmesi”. Kastamonu Eğitim Dergisi 27/3 (2019), 1015-1021. https://doi.org/10.24106/kefdergi.2369

Farber, Leslie H. The Ways of the Will. New York: Basic Books, 1966.

Feather, Norman T. - Sherman, Rebecca. "Envy, Resentment, Schadenfreude, and Sympathy: Reactions to Deserved and Underserved Achievement and Subsequent Failure". Personality and Social Psychology Bulletin 28/7 (2002), 953-961. https://doi.org/10.1177/01467202028007008

Feather, Norman T. - Nairn, Katherine. "Resentment, Envy, Schadenfreude, and Sympathy: Effects of Own and Other's Deserved or Undeserved Status". Australian Journal of Psychology 57/2 (2005), 87-102. https://doi.org/10.1080/00049530500048672

Feather, Norman T. - McKee, Ian R. "Differentiating Emotions in Relation to Deserved or Undeserved Outcomes: A Retrospective Study of Real-life Events". Cognition \& Emotion 23/5 (2009), 955-977. https://doi.org/10.1080/02699930802243378

Foster, George M. “The Anatomy of Envy: A Study in Symbolic Behaviour”. Current Anthropology 13 (1972), 165-202. https://doi.org/10.1086/201267 
Gazâlî, Ebû Hâmid Muhammed b. Muhammed. Kimyâ-i Saâdet. çev. A. Faruk Meyan. 2 Cilt. İstanbul: Bedir Yayınları, 1990.

Gazâlî, Ebû Hâmid Muhammed b. Muhammed. İhyâ-i 'Ulûmi'd-Dîn. çev. Ahmet Serdaroğlu. 4 Cilt. İstanbul: Bedir Yayınları, 2019.

Gressel, Josh. Embracing Envy: Finding the Spiritual Treasure in Our Most Shameful Emotion. Lanham: University Press of America, 2014.

Gürses, İbrahim. Dindarlık ve Kişilik. Bursa: Emin Yayınları, 2010.

Habimana, Emmanuel - Massé, Line. "Envy Manifestations and Personality Disorders". European Psychiatry 15 (2000), 15-21. https://doi.org/10.1016/S09249338(00)00501-0

Hacker, P.M.S. The Passions: A Study of Human Nature. Oxford: Wiley Blackwell, 2018.

Hareli, Shlomo - Weiner, Bernard. "Dislike and Envy as Antecedents of Pleasure at Another's Misfortune". Motivation and Emotion 26/4 (2002), 257-277. https://doi.org/10.1023/A:1022818803399

Henniger, Nicole E - Harris, Christine R. “Can Negative Social Emotions Have Positive Consequences?: An Examination of Embarrassment, Shame, Guilt, Jealousy, and Envy". The Positive Side of Negative Emotions. ed. W. Gerrod Parrott. 76-97. New York: The Guilford Press, 2014.

İbn Hazm. Ahlak ve Davranış Tarzları Nefislerdeki Ahlâkî Hastalıkların Tedavisi. çev. Mustafa Çağrıcı. 2. Basım. Ankara: TDV Yayınları, 2015.

İbn Kayyım el-Cevziyye. İbn Kayyim Tefsiri: Bedâi'u't-tefsîr. der. Yüsrî es-Seyyid Muhammed. çev. Mehmet Ali Kara vd. İstanbul: Karınca \& Polen Yayınları, 2011.

İbn Kayyım el-Cevziyye. Allah Sevgisi. çev. İshak Emin Aktepe - Ahmet Akbaş. İstanbul: Karınca \& Polen Yayınları, 2012.

İsfahânî, Ebu'l-Kāsım er-Râgıb. Müfredât: Kur'ân Kavramları Sözlüğü. çev. Abdulbaki Güneş - Mehmet Yolcu. İstanbul: Çıra Yayınları, 2012.

İsfahânî, Ebū'l-Kâsım er-Râgıb. ez-Zerî‘a ilâ makāmi'l-şerî‘a: Erdemli Yol. çev. Muharrem Tan. İstanbul: İz, 4.Basım, 2019.

Joseph, Betty. "Envy in Everyday Life”. Psychoanalytic Psychotherapy 2/1 (1986), 13- 22. https://doi.org/10.1080/02668738600700021

Kernberg, Otto. Aggressivity, Narcissism, and Self-destructiveness in the Psychotherapeutic Relationship: New Developments in the Psychopathology and Psychotherapy of Severe Personality Disorders. New Heaven and London: Yale University Press, 2004.

Kets de Vries, Manfred F.R. Sex, Money, Happiness, and Death: The Quest for Authenticity. New York: Palgrave Macmillan, 2009. 
Kınalızâde Ali Efendi. Ahlâk-ı Alâî. haz. Hüseyin Algül. İstanbul: Tercüman 1001 Temel Eser, ts.

Kilborne, Benjamin. Utanç ve Haset: Görünüm Kaygısı ve Kem Göz. çev. Burçak Erdal. ed. Sibel Mercan. İstanbul: İstanbul Bilgi Üniversitesi, 2014.

Kuipers, Giselinde. "Schadenfreude and Social life: A Comparative Perspective on the Expression and Regulation of Mirth at the Expense of Others". Schadenfreude: Understanding Pleasure at the Misfortune of Others. ed. Wilco W. van Dijk - Jaap W. Ouwerkerk. 259-274. Cambridge: Cambridge University Press, 2014.

Kur'ân-ı Kerîm Meâli. çev. Halil Altuntaş - Muzaffer Şahin. Ankara: DİB Yayınları, 13.Basim, 2012.

Kurtubî, Ebû Abdillah Muhammed b. Ahmed. el-Câmi 'li Ahkâmi'l-Kur'ân. çev. M. Beşir Eryarsoy. 20 Cilt. İstanbul: Buruc Yayınları, 1997.

Lange, Jens - Crusius, Jan. "Dispositional Envy Revisited: Unraveling the Motivational Dynamics of Benign and Malicious Envy". Personality and Social Psychology Bulletin 41/2 (2015), 284-294. http://dx.doi.org/10.1177/0146167214564959

Lazarus, Richard. S. Emotion and Adaptation. NY: Oxford University Press, 1991.

Lazarus, Richard S. - Lazarus, Bernice N. Passion and Reason: Making Sense of Our Emotions. Oxford: Oxford University Press, 1994.

Leach, Colin Wayne - Spears, Russell. "A Wengefulness of the Impotent: The Pain of in-group Inferiority and Schadenfreude Toward Successful Out-groups". Journal of Personality and Social Psychology 95/6 (2008), 1383-1396.

https://doi.org/10.1037/a0012629

Leach, Colin Wayne vd., "Situating Schadenfreude in Social Relations". Schadenfreude: Understanding Pleasure at the Misfortune of Others. ed. Wilco W. van Dijk - Jaap W. Ouwerkerk. 200-216. Cambridge: Cambridge University Press, 2014.

Mâverdî, Ebu'l-Hasen. Yüce Hedefler Kitabı. çev. Ahmed Cevdet Efendi. İstanbul: Büyüyen Ay Yayınları, 2. Basım, 2013.

Miceli, Maria - Castelfranchi, Cristiano. "The Envious Mind". Cognition and Emotion 21/3 (2007), 449-479. https://doi.org/10.1080/02699930600814735

Muhâsibî, Haris b. Esed. er-Riâye: Nefs Muhasebesinin Temelleri. çev. Şahin Filiz - Hülya Küçük. İstanbul: İnsan Yayınları, 4. Basım, 2011.

Navaro, Leyla - Schwartzberg, Sharan L. "Conclusions and Therapeutic Implications". Envy, Competition and Gender: Theory, Clinical Applications and Group Work. ed. Leyla Navaro -Sharan L. Scwartzberg. 205-211. New York, NY: Routledge, 2007.

Navaro, Leyla. Haset ve Rekabet Kendi Kuyruğunu Yiyen Yılan. İstanbul: Remzi Yayınevi, 3. Basim, 2015. 
Nevevî, Ebû Zekeriyyâ Muhyiddin Yahyâ b. Şeref b. Muri. Riyâzü’s-Sâlihîn. çev.- şerh. M. Yaşar Kandemir vd. 8 Cilt. İstanbul: Erkam Yayınları, 2009.

Ninivaggi, Frank John. Envy Theory: Perspectives on the Rsychology of Envy. Lanham, MD: Rowman \& Littlefield Publishers, 2010.

Özakkaş, Tahir. Bütüncül Psikoterapi. İstanbul: Litera Yayıncılık, 8. Basım, 2016.

Parrott, W. Gerrod. “The Emotional Experience of Envy and Jealousy”. The Psychology of Jealousy and Envy. ed. Peter Salovey. 3-30. New York: Guilford Press, 1991.

Pines, Ayala Malach. Aşk ve Kıskançlık. çev. Canan Yonsel. İstanbul: Okyanus Yayınları, 2003.

Powell, Caitlin A. J. vd. "Schadenfreude Caused by an Envied Person's Pain”. Series in Affective Science. Envy: Theory and Research. ed. Richard H. Smith. 148-164. New York: Oxford University Press, 2008.

Power, Mick - Dalgleish, Tim. Cognition and Emotion: From Order to Disorder. Hove, U.K.: Taylor Francis, 2.Basım, 2007.

Protasi, Sara. “Varieties of Envy”. Philosophical Psychology 29 (2016), 535-549.

Quintanilla, Laura - Jensen de López, Kristine. "The Niche of Envy: Conceptualization, Coping Strategies, and the Ontogenesis of Envy in Cultural Psychology". Culture \& Psychology 19/1 (2013), 76-94. https://doi.org/10.1177/1354067X12464980

Rawls, John. A Theory of Justice. Cambridge, MA: Harvard University Press, 1971.

Râzî, Fahreddin. Tefsîr-i Kebîr Mefâtîhu'l-Gayb. çev. Suat. Yıldırım vd. 23 Cilt. Ankara: Akçağ Yayınları, 1988-2002.

Salovey, Peter - Rodin, Judith. "Coping with Envy and Jealousy". Journal of Social and Clinical Psychology 7/1 (1988), 15-33. https://doi.org/10.1521/jscp.1988.7.1.15

Schimmel, Solomon. "Envy in Jewish Thought and Literature". Envy: Theory and Research. ed. Richard H. Smith. 17-38. New York: Oxford University Press, 2008.

Schoeck, Helmut. Envy: A Theory of Social Behavior. New York: Harcourt, Brace \& World, 1969.

Semerkandî, Ebu'l-Leys Nasr b. Muhammed b. Ahmed b. İbrâhim. Tefsîru'l-Kur'an. çev. Mehmet Karadeniz. 6 Cilt. İstanbul: Özgü Yayınları, 1993.

Shrand, Joseph - Devine, Leigh. Outsmarting Anger: 7 Strategies for Defusing Our Most Dangerous Emotion. San Francisco: Jossey-Bass, 2013.

Smith, Richard H. vd., "Envy and Jealousy Semantic Problems and Experiential Distinctions". Personality and Social Psychology Bulletin 14/2 (1988), 401-409. https://doi.org/10.1177/0146167288142017 
Smith, Richard H. "Envy and the Sense of Injustice". The Psychology of Jealousy and Envy. ed. Peter Salovey. 79-99.New York and London: Guilford Press, 1991.

Smith, Richard H. vd., "Subjective Injustice and Inferiority as Predictors of Hostile and Depressive Feelings in Envy". Personality and Social Psychology Bulletin 20/6 (1994), 705-711. https://doi.org/10.1177/0146167294206008

Smith, Richard H.vd., "Envy and Schadenfreude". Personality and Social Psychology Bulletin 22/2 (1996), 158-168. https://doi.org/10.1177/0146167296222005

Smith, Richard H. - Kim, Sung Hee. "Comprehending Envy”. Psychological Bulletin 133/1 (2007), 46-64. https://doi.org/10.1037/0033-2909.133.1.46

Smith, Tiffany Watt. Schadenfreude: Başkasının Talihsizliğinden Duyulan Keyif. çev. Nüvit Bingöl. İstanbul: Kolektif Kitap, 2. Basım, 2020.

Spielman, Philip M. "Envy and Jealousy an Attempt at Clarification". Psychoanalytic Quarterly 40 (1971), 59-82.

Strongman, Kenneth T. The Psychology of Emotion, from Everyday life to Theory. England: John Wiley \& Sons Ltd., 5. Basim, 2003.

Taburoğlu, Özgür. Nazar Başkası Nasıl Görür?. Ankara: Doğu Batı Yayınları, 2017.

Testa, Maria - Major, Brenda. "The Impact of Social Comparison After Failure: The Moderating Effects of Perceived Control”. Basic and Applied Social Psychology 11 (1990), 205-218. https://doi.org/10.1207/s15324834basp1102_7

Van de Ven, Niels vd., "Leveling up and down: The Experiences of Benign and Malicious Envy”. Emotion 9/3 (2009), 419-429. https://doi.org/10.1037/a0015669

Van de Ven, Niels vd., "Why Envy Outperforms Admiration". Personality and Social Psychology Bulletin 37/6 (2011), 784-795. https://doi.org/10.1177/0146167211400421

Van Dijk, Wilco W vd. "Self-esteem Self-affirmation and Schadenfreude". Emotion 11/6 (2011a), 1445-1449. https://doi.org/10.1037/a0026331

Van Dijk, Wilco W. - Ouwerkerk, Jaap W. "Introduction to Schadenfreude". Schadenfreude: Understanding Pleasure at the Misfortune of Others. ed. Wilco W. van Dijk - Jaap W. Ouwerkerk. 1-13. Cambridge: Cambridge University Press, 2014.

Vidaillet, Bénédicte. Workplace Envy. London: Palgrave McMillan, 2008.

Yazçiçek, Ramazan. Haset. İstanbul: Ekin Yayınları, 2.Basım, 2014.

Yazır, E. M. Hamdi. Hak Dini Kur'ân Dili. sad. İsmail. Karaçam vd. 10 Cilt. İstanbul: Zehraveyn Yayınları, 1992. 


\section{The Destructive Effects of Envy in Human Life and the Search for Solutions}

\section{Extended Summary}

Envy, which is a universal and common emotion, appears as a powerful reality that affects the behavior of the individual. This emotion, which is not a momentary emotional state, continues its existence and effect for a long time. It has a comprehensive relationship with emotions such as jealousy, schadenfreude, and benign envy. The feeling of envy, which is used synonymously with jealousy in daily life, differs from the feeling of jealousy in terms of cognitive, emotional and motivational aspects. At its most basic level, envy involves the desire to get what someone else has, while jealousy is associated with a sense of protecting possessions. The schadenfreude is defined as taking pleasure in the failure and defeat of the other. There is a belief that one deserves the misfortunes that befall him. There is a significant relationship between this emotion and envy, deservingness, goaldirected negative emotions, low self-esteem, inferiority feeling, and the schadenfreude.

Envy is an emotion that is mostly denied because it is an emotion that is not approved by the society. Because envy has been condemned/vilified in religious traditions and cultural taboos. This makes it difficult to openly admit envy. Thus, envy appears in various forms, often being rejected, suppressed, or masked.

It is not possible to reduce the feeling of envy, which expresses a semantically negative situation, to a single cause. Variables such as negative social comparison, low self-esteem, feelings of inadequacy, feelings of inferiority, and perception of injustice can be shown among the main factors that trigger or provoke the feeling of envy. In particular, negative social comparison seriously damages the self-esteem of the individual and may reveal emotions such as anger, resentment, jealousy, shame, ill-will, and hostility. Envy, which is an obstacle to an individual's effective use of mental resources, is a source of unbearable pain and suffering. He is in a constant state of sadness. He feels frustrated, unsuccessful, and defeated. The envious, who partially or completely blocks the ways of participating in society by reproduction, does not prefer to develop his skills. When envy is excessive, it may exhibit a pathological appearance. The inner balance and harmony of the individual is seriously impaired. Envy can form part of serious disorders such as anxiety, affective disorders, narcissistic and borderline personality disorders.

While the feeling of envy, which affects the spiritual, social and mental world of the person, causes various destructive and disruptive situations in the life of the individual, on the other hand, it can evolve into a feeling of benign envy and bring new initiatives and different experiences to the individual with a functional and transformative effect. While envy includes behaviors such as bringing down or prevention the other person with ill-will and hostility, benign envy includes 
admiration and appreciation and the desire to be equal to or surpass the other person without harming them.

In Islamic thought, envy is seen as a feeling that leads to evil, endangers the happiness of the world and the hereafter, leads to rebellion against Allah, and prevents spiritual gains. Because there is information in Islamic sources that envy is the source of various attitudes and behaviors, from passive reactivity to fatal aggression, intertwined with the feeling of jealousy. Because of these malicious consequences, envy has been mentioned as an emotion that needs refuge in Allah. On the other hand, benign envy was encouraged in the religion of Islam and was seen as a reflection of goodwill, pleasant and beneficial behaviors. Because in this feeling, it is not desirable that the blessing that is in someone else disappears. On the contrary, besides wishing for the increase of goodness and beauty, it is desired for believers to strive in this direction.

Envy is a feeling that has existed in every society and environment from past to present. Therefore, trying to eliminate envy itself is not a meaningful attitude. In order to comprehend the nature of the effect of envy and to be protected from its harmful effects, it is necessary to be aware of the feeling of envy first. This allows us to see and thus prevent some negative reactions and consequences before they occur. Secondly, trying to understand the situations that cause the destructive and disruptive aspects of envy to dominate and learning from which experiences it feeds is another important step in the treatment of this emotion. On the other hand, religion offers security and relief to those who are envied by taking refuge in Allah. For this, it is necessary to connect to Allah with an internalized consciousness, to be in peace with His will, and to strive to understand the values of divine origin. In this way, success is possible in dealing with envy.

Keywords: Envy, Jealousy, Schadenfreude, Benign Envy, Social Comparison, Mental Health. 